
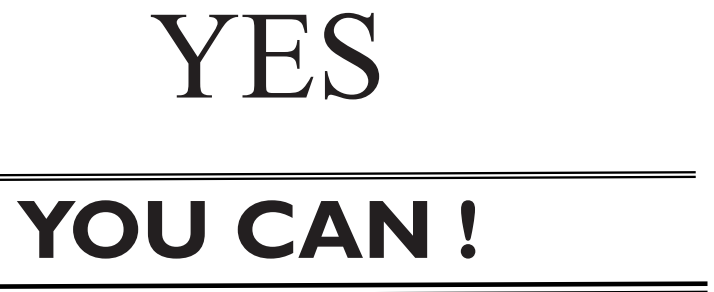

María E. Zambrano Saavedra

Claudia K. Loor Caicedo

Fresia M. Véliz Robles

Bella N. Tumbaco Zambrano

María S. Williams Zambrano

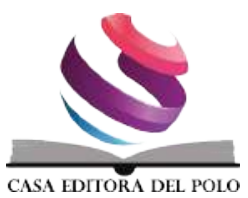





\title{
YES YOU CAN !
}

\author{
(C) Autores
}

María E. Zambrano-Saavedra

Docente de la Universidad Laica Eloy Alfaro de Manabí

Claudia K. Loor-Caicedo

Docente de la Universidad Laica Eloy Alfaro de Manabí

Fresia M. Véliz-Robles

Docente de la Universidad Laica Eloy Alfaro de Manabí

Bella N. Tumbaco-Zambrano

Docente de la Universidad Laica Eloy Alfaro de Manabí

María S. Williams-Zambrano

Docente de la Universidad Laica Eloy Alfaro de Manabí 



\section{Casa Editora del Polo - CASEDELPO CIA. LTDA. \\ Departamento de Edición}

\section{Editado y distribuido por:}

(C) Casa Editora del Polo

Sello Editorial: 978-9942-816

Manta, Manabí, Ecuador. 2019

Teléfono: (05) 6053240

https://www.casedelpo.com/

ISBN: 978-9942-980-31-1

(C) Primera edición

(C) Octubre - 2019

Impreso en Ecuador

\section{Revisión, Ortografía y Redacción:}

Lic. Jessica María Mero-Vélez

Diseño de Portada:

Michael Josué Suárez-Espinar

\section{Diagramación:}

Ing. Edwin Alejandro Delgado-Veliz

\section{Director Editorial:}

PhD. Julio Juvenal Aldana -Zavala

Todos los libros publicados por la Casa Editora del Polo, son sometidos previamente a un proceso de evaluación realizado por árbitros calificados.

Este es un libro digital y físico, destinado únicamente al uso personal y colectivo en trabajos académicos de investigación, docencia y difusión del Conocimiento, donde se debe brindar crédito de manera adecuada a los autores.

(C) Reservados todos los derechos. Queda estrictamente prohibida, sin la autorización expresa de los autores, bajo las sanciones establecidas en las leyes, la reproducción parcial o total de este contenido, por cualquier medio o procedimiento.parcial o total de este contenido, por cualquier medio o procedimiento. 



\section{Comité Científico Académico}

Dr. Lucio Noriero Escalante

Universidad Autónoma de Chapingo, México.

Dra. Yorkanda Masó Dominico

Instituto Tecnológico de la Construcción, México.

Dr. Juan Machado

Universidad de Granma, Bayamo. M.N. Cuba.

Dra. Fanny Miriam Sanabria Boudri

Universidad Nacional Enrique Guzmán y Valle, Perú.

Dra. Jennifer Quintero Medina

Universidad Privada Dr. Rafael Belloso Chacín. Venezuela.

Dr. Félix Colina Ysea

Universidad SISE. Lima, Perú.

Dr. Reinaldo Velasco

Universidad Bolivariana de Venezuela

Dra. Katiusca Josefina Peña Colina

Universidad Nacional Experimental Francisco de Miranda, Venezuela

Dra. Eira Makarena Urbina Jiménez

Universidad Nacional Experimental de la Seguridad 



\section{Constancia de Arbitraje}

La Casa Editora del Polo, hace constar que este libro proviene de una investigación realizada por los autores, siendo sometido a un arbitraje bajo el sistema de doble ciego (peer review), de contenido y forma por jurados especialistas. Además, se realizó una revisión del enfoque, paradigma y método investigativo; desde la matriz epistémica asumida por los autores, aplicándose las normas APA, Sexta Edición, proceso de anti plagio en línea Plagiarisma, garantizándose así la cientificidad de la obra.

\section{Comité Editorial}

Abg. Néstor D. Suárez-Montes

Casa Editora del Polo (CASEDELPO)

Dra. Juana Cecilia-Ojeda

Universidad del Zulia, Maracaibo, Venezuela

Dra. Maritza Berenguer-Gouarnaluses

Universidad Santiago de Cuba, Santiago de Cuba, Cuba

Dr. Víctor Reinaldo Jama-Zambrano

Universidad Laica Eloy Alfaro de Manabí, Ext. Chone

Dra. Ana Cristina Chirinos-Martínez

Universidad Nacional Experimental Francisco de Miranda, Venezuela

Dr. Miguel Ángel Perozo-Ynestroza

Universidad Nacional Experimental Francisco de Miranda, Venezuela 



\section{CONTENIDO}

Prólogo .............................................. 13

Lesson 1. Spell this word.....................................19

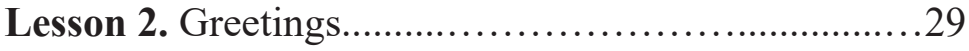

Lesson 3. Introducing yourself and Introducing someone else.

Lesson 4. Can you tell me the time, please?..................61

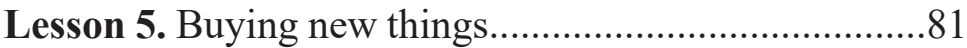

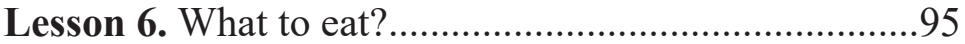

Lesson 7. Where to go? ...............................................113

Lesson 8. What do you do?.........................................123

Lesson 9. Let's go to the cinema..................................133

Lesson 10. Let's study at the university........................141

English texts to practice Reading (Short Texts)............153

English texts to practice Reading (Long Texts)............159

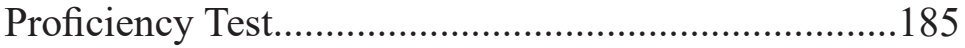

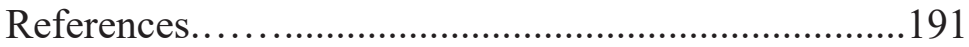





\section{Prólogo}

Yes, you can! Es un libro estructurado con un contenido sumamente didáctico para el aprendizaje del inglés. Este libro contiene una serie de expresiones de la vida cotidiana que pueden ser usadas por un hablante de inglés en el día a día.

El texto es ajustado a un nivel básico, con estructuras sencillas e ilustradas fáciles de entender para aprendices de la etapa universitaria. Los temas giran en torno al deletreo de distintas palabras, saludos, presentaciones, despedidas, ocupaciones, localizaciones de lugares, pedir y decir la hora, entre otros que son esenciales para la comunicación con hablantes nativos. De este modo, se abordan diez lecciones que son sumamente fundamentales para un dominio base de la lengua extranjera.

En este sentido, el primer contenido se denomina "Spell this word", tal tema se basa en el deletreo de palabras comunes, nombres y apellidos de personas. El segundo contenido se basa en "Greetings", en el que se exponen distintas expresiones para saludar y despedirse. El tercer tema "Introducing yourself and Introducing someone else", es contentivo de vocabulario frases y expresiones para presentarse a sí mismo y a los demás. Asimismo, se aborda el tema "Can you tell me the time, please?", mediante el cual los aprendices pondrán en práctica preguntas y respuestas correctas para decir la hora. Por otro lado, se presenta el tema "Buying new 
things", a fin de que el hablante pueda comunicarse en una tienda de ropa, víveres, entre otros.

El siguiente contenido se denomina "What to eat?", que facilita el llevar a cabo conversaciones en un restaurante o en la casa. En el tema "Where to go?", se muestran expresiones diversas para invitar a salir. En el contenido "What do you do?", se habla de ocupaciones, en "Let's go to the cinema", se emplean expresiones dentro y fuera del cine y Let's study at the university, implica el uso de frases a usar en conversaciones comunes con los compañeros acerca de las actividades a realizar en la misma.

Por otra parte, vale resaltar que en cada tema se aborda el vocabulario, la práctica oral, y escrita, de comprensión auditiva y lectora. Al final del libro, tanto el docente como los estudiantes cuentan con una serie de lecturas tomadas de distintas páginas web a fin de estimular esta habilidad y dejar a criterio del docente las actividades a realizar en cada una de ellas. También se propone una prueba de suficiencia que podría aplicarse a fin de diagnosticar el nivel de conocimiento que poseen los estudiantes antes de iniciar el estudio del idioma con el libro.

Desde el punto de vista de la gramática, se muestran algunas estructuras que orientan el uso correcto de ciertas frases a considerar al momento de hablar como base sintáctica y semántica del idioma inglés. Es importante señalar que las referencias bibliográficas 
consultadas fueron empleadas como orientación para el diseño del libro y su contenido.

En atención a lo expuesto, vale resaltar que el libro constituye una guía significativa tanto para el docente como para el estudiante, ya que muestra de forma detallada las distintas maneras de comunicarse en el idioma meta.

Finalmente, es importante acotar que toda la información fue elaborada con el fin de promover un aprendizaje óptimo para un uso adecuado de todas las opciones comunicativas que propician una comunicación fluida y espontánea. 



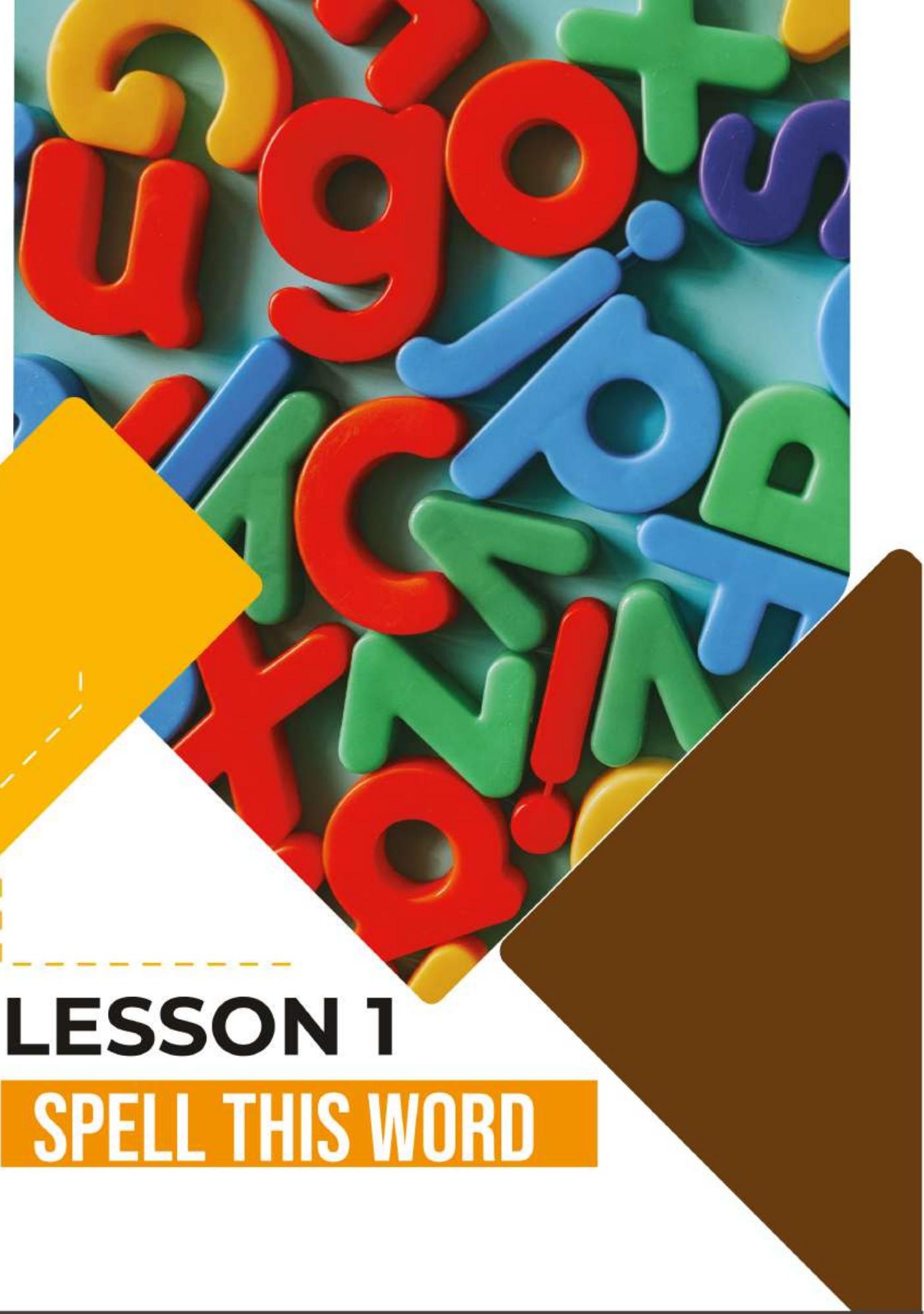




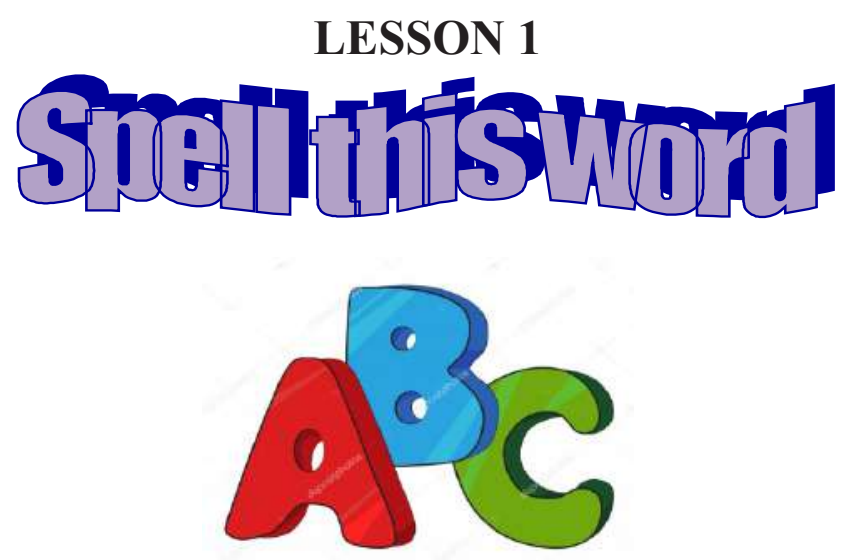

Let's practice the alphabet.

\begin{tabular}{|l|l|l|l|l|l|l|}
\hline A:ei & B:bi & C:si & D:di & E:i & F:ef & G:yi \\
\hline H:eich & I:ai & J:yei & K:kei & L:el & M:em & N:en \\
\hline O:ou & P:pi & Q:kiu & R:ar & S:es & T:†i & U:iu \\
\hline V:vi & W:dobliu & X:ex & Y:uai & Z:zi & & \\
\hline
\end{tabular}

To ask a person to spell some words, we can ask these questions:

1. How do you spell this word?

2. How do you spell your first name?

3. How do you spell your second name?

4. How do you spell your last name?

See this conversation and practice:

A: What's your name? 
C: Stephen Brown

A: How do you spell your first name?

C: S: es- T: ti-E: i-P: pi-H: eich-E: i- N: en.

$A:$ Is it S: es- T: ti- E: i-P: pi- H: eich- E: i- N: en?

C: Yes, it is.

A: How do you spell your last name?

C: B: bi- R: ar- O: ou- W: dobliu- N: en.

$A$ : Is it B: bi- R: ar- O: ou- W: dobliu- N: en?

C: Yes, it is.

A: Ok, thanks.

C: You're welcome.

Act it out!

Answer the following questions and spell your names:

-What's your name?

-How do you spell your first name? 
-How do you spell your last name?

\section{English Song}

\section{Letters}

$$
\begin{gathered}
a-b-c-d-e-f-g \\
(e i)-(b i)-(s i)-(d i)-(i)-(e f)-(y i)
\end{gathered}
$$

Walk and walk and walk with me

$$
\text { h- i-j-k- l- m- n- }
$$

$$
\text { (eich)- (ai)- (yei)- (kei)- (el)- (em)- (en) }
$$

Run and come right here again

$$
\begin{gathered}
\text { o- } \mathbf{p}-\mathbf{q}-\mathbf{r - s - t - u} \\
\text { (ou)- (pi)- (Kiu)- (ar)- (es)- (ti)- }
\end{gathered}
$$

I would like to dance with you

$$
\begin{gathered}
v-w-x-y-z \\
(v i)-(\text { dabliu)- (eks)- (uai)- (zi) }
\end{gathered}
$$

Have a seat right now like me.

Taken from: García, 2009. 


\section{YES YOU CAN！}

\section{Exercises}

Now, tell us the meaning of the following vocabulary and spell each word:

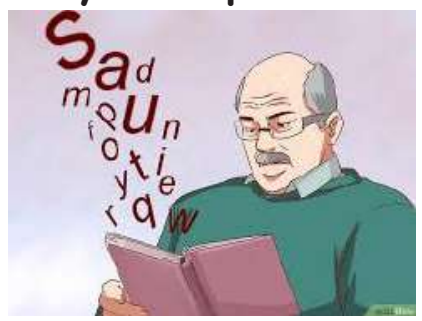

\section{Vocabulary}

-Days of the week: Sunday-Monday- TuesdayWednesday- Thursday- Friday- Saturday.

-Months of the year: January-February-MarchApril- May- June- July- August- September- October- November- December

-Colors: yellow- blue- red- white- black- greygreen- orange- pink- purple-red wine. 


\section{Let's play}

\section{Word Search}

Brown ( )- Yellow ( )- March ( )-December

( ) - Sunday

\begin{tabular}{|l|l|l|l|l|l|l|l|l|l|l|l|l|}
\hline B & I & P & D & H & I & J & W & O & L & L & E & Y \\
\hline O & R & D & O & H & P & I & N & K & M & N & R & A \\
\hline F & D & O & C & P & L & E & I & P & T & A & B & D \\
\hline D & N & R & W & E & R & U & R & G & D & P & L & N \\
\hline S & A & W & U & N & D & Y & P & U & R & L & A & U \\
\hline M & G & D & E & C & E & M & B & E & R & Q & K & S \\
\hline
\end{tabular}

Taken from: García, 2009

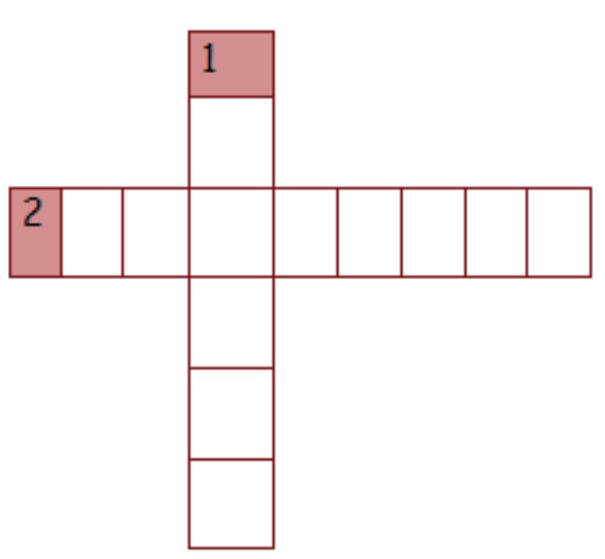

Days of the week

Down

1. The first day of the week is:

Across:

2. The fourth day of the week is:

Taken from: García, 2009 


\section{GRAMMAR}

\begin{tabular}{|c|c|}
\hline \multicolumn{2}{|c|}{ You can use: } \\
\hline $\begin{array}{l}\text { What is... ? or the } \\
\text { contraction What's...? }\end{array}$ & $\begin{array}{l}\text { My name is... } \\
\text { My name's... }\end{array}$ \\
\hline What's your name? & $\begin{array}{l}\text { I am... } \\
\text { I'm... }\end{array}$ \\
\hline Is it...? & $\begin{array}{l}\text { It is... } \\
\text { It's... }\end{array}$ \\
\hline Is it Helen? & $\begin{array}{l}\text { Yes, it is. } \\
\text { No, it isn't. }\end{array}$ \\
\hline
\end{tabular}

Now practice with a partner considering all the options given:

1. What's your name? Is it Helen?

2. What is your name? Is it Paul? 


\section{Reading}

\section{Writing application letter}

A letter of application should create enough interest to make the potential employer want to look at your application in greater detail by reading your $\mathrm{CV}$ and hopefully invite you for an interview. Your application letter, however, should not contain too much detail about your experience and qualifications because that is the job of the $C V$.

Layout and style

The letter should be limited to one page and a few paragraphs will normally be sufficient. It is better to address a letter to a specific person, e.g. Dear Miss Chan, rather than to Dear Sir or Madam. However, in some job advertisements the name of the person you are writing to is not given. It is good practice to try to find out the following information before you write your letter:

- The full name of the person you are writing:

- Their title - Mr., Mrs., Miss, Ms, Dr, Professor, etc, and;

- Their position - Personnel Manager, Human Resources Manager, etc.

All this information can be obtained by a quick phone call to the company. Remember, never write Dear Miss W. Chan. It should be Dear Miss Chan. Do not use the initial except in the address. If you start with Dear Sir/Madam, it is accepted 


\section{YES YOU CAN !}

practice to finish with Yours faithfully. Whereas, if you start with Dear Miss Chan, you may finish with Yours sincerely. Your letter should be neat and free from careless mistakes. You can follow the blocked and open punctuation style. Whichever layout style you choose to use, you should use it consistently throughout the letter.

Write a letter taking into account the aspects specified above: 



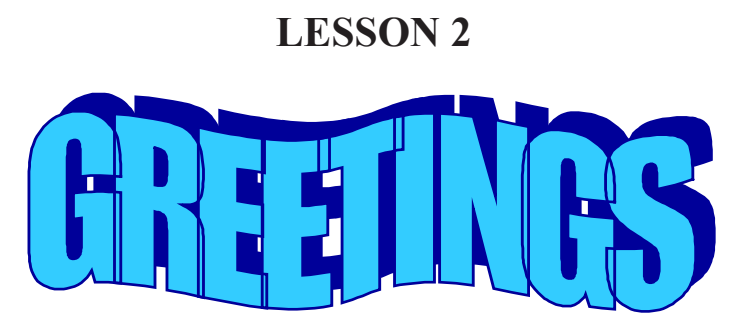

To say hello...

\begin{tabular}{|l|}
\hline Good afternoon \\
\hline Good evening \\
\hline Good morning \\
\hline Hello \\
\hline Hi \\
\hline How are things? \\
\hline How are you doing? \\
\hline How are you? \\
\hline How do you do? \\
\hline How's it going? \\
\hline How's the family? \\
\hline Welcome \\
\hline What's going on? \\
\hline What's new? \\
\hline What's up? / What's happening? \\
\hline Nice to see you \\
\hline
\end{tabular}

Some answers...

-I am Fine

-I'm fine 
-Just fine

-I am very well

-I'm very well

-I don't feel well

-I'm not so good

-More and less

-So so.

Farewells:

--Bye

-Good bye

- See you then

-See you later

-See you

-See you tomorrow

-See you on saturday

-See you next week 
-See you next month

-See you next year

- Till tomorrow

-It was nice to see you.

-So long!

-Good night

\section{Practice these dialogues}

Situation: The student gets late and greets the teacher.
A: Hello, teacher. How are you?
B: I'm fine. And you?

A: Good. Sorry for being late. Public transportation is abysmal nowadays.

B: Don't worry. Try to be earlier next time.

A: I'll do my best to be on time. 


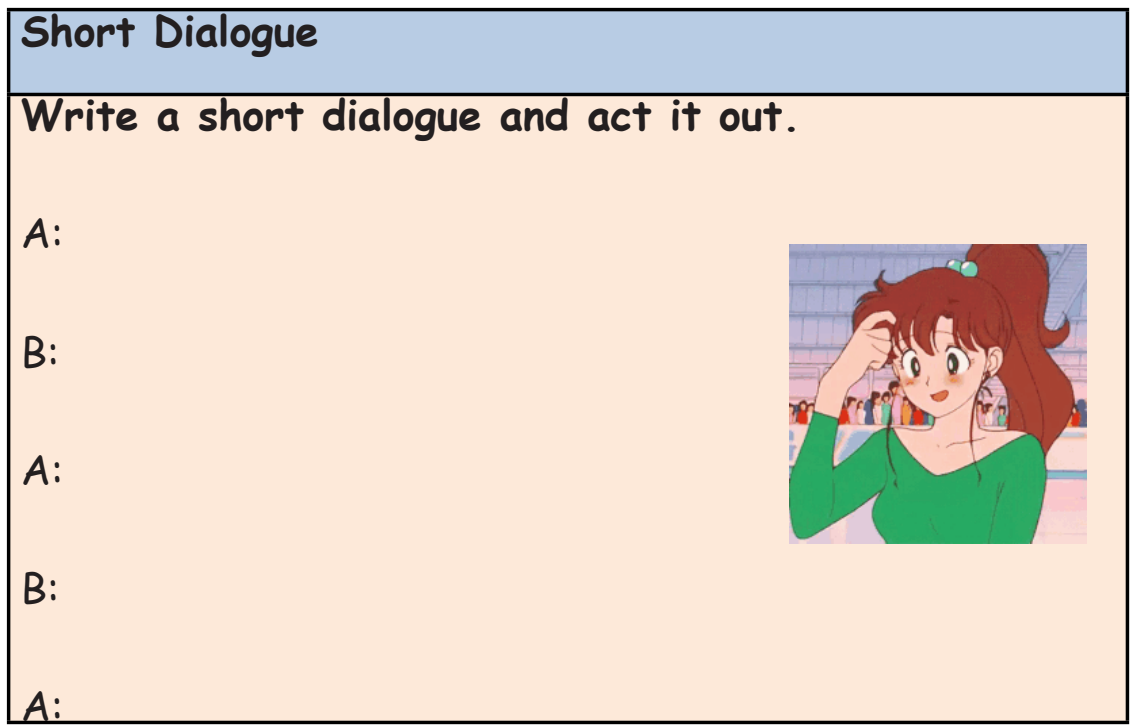

Check the pronunciations of the following dialogues by clicking this link.

https://www.eslfast.com/robot/topics/smalltalk/ smalltalk01.htm

A: Hi, howt are you doing?

B: I'm fine. How about yourself?

A: I'm pretty good. Thanks for asking.

B: No problem. So how have you been?

A: I've been great. What about you?

$B$ : I've been good. I'm in school right now.

A: What school do you go to?

B: I go to PCC.

A: Do you like it there?

B: It's okay. It's a really big campus. 

A: Good luck with school.
$B$ : Thank you very much.

A: How's it going?

B: I'm doing well. How about you?

A: Never better, thanks.

B: So how have you been lately?

A: I've actually been pretty good. You?

B: I'm actually in school right now.

A: Which school do you attend?

B: I'm attending PCC right now.

$A$ : Are you enjoying it there?

B: It's not bad. There are a lot of people there.

A: Good luck with that.

B: Thanks.

A: How are you doing today?

B: I'm doing great. What about you?

A: I'm absolutely lovely, thank you.

B: Everything's been good with you?

A: I haven't been better. How about yourself? 
B: I started school recently.

A: Where are you going to school?

B: I'm going to PCC.

A: How do you like it so far?

B: I like it so far. My classes are pretty good right now.

A: I wish you luck.

B: Thanks a lot.

Complete this dialogue according to the options given in parentheses:

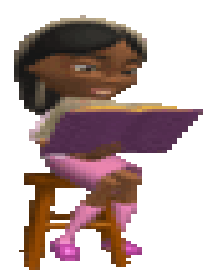

(I-know- are- thanks-can-fine- eraser-me- repeat-eraser-didn't-about- morning-I)

Teacher: Good Morning, students. How you?

Students: Good

Fine, teacher.

Teacher: And you?

Student 1: Teacher, may ask you a question? 
Teacher: Yes, sure.

Student 1: How I say borrador in English?

Teacher: The correct word is

Student 2: Excuse stand. Can you I please? under-

Teacher: Yes, of course. The correct word for borrador is

Student 3: What is the class

Teacher: It's about the colors. Do you know how to say marrón in English?

Student 2: I don't

Student 3: Yes, know. It's brown.

Teacher: Good!

\section{Vocabulary}

-Check the following vocabulary:

Hi- Hello- Great- Wonderful- attend- thanks- thank you- How about you?- early- late- what- where- whenwho- how.

\section{List of School Supplies}

- Desk

- Highlighter

- Book

- Notebook

- Pencil case 
- Backpack

- Scissors

- Pencil

- Rubber(U.K) - eraser (U.S)

- Compass

- Binder

- Pins

- Flask

- Clip

- Ruler

- Coloured pencil (U.K) - Colored pencils (U.S)

- Pencil sharpener

- Stapler

- Calculator

- Scotch tape

- Glue

- Funnel

- Beaker

- Test tube

- Globe

Let's practice. 


\section{School Supplies}

These are books.

This is a notebook

These are scissors.

It's a glue

It's a tape.

ec This is a pencil case. 
This is a pencil.

This is a pen.

This is an eraser.

It's a highlighter.

It is a ruler.

These are my color pencils.

This is a sharpener. 


\section{Example,}

\section{This}

That

These

Those

\section{Practice}

What is this?

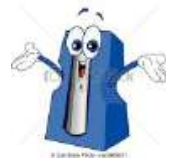

What is that?

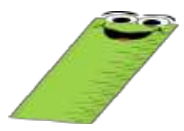

What are these?

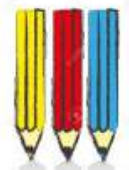

What are those?

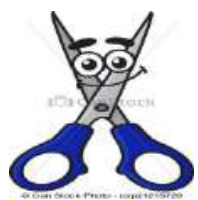




\section{GRAMMAR}

\section{You can use:}

How are you?

To answer, you can say:

Fine

I am fine

I'm fine

As you can see, you can use the contraction ('m) to use the verb to be in a short and simple way.

The same happens with:

You're-He's-She's-We're- they're

The verb to be

\begin{tabular}{|c|c|c|c|}
\hline $\begin{array}{c}\text { Personal } \\
\text { Pronouns }\end{array}$ & $\begin{array}{c}\text { Verb to } \\
\text { be }\end{array}$ & Questions & Answers \\
\hline I & Am & Are you...? & I am o I'm \\
\hline $\begin{array}{c}\text { You (singu- } \\
\text { lar) }\end{array}$ & Are & Am I...? & You are o You're \\
\hline He & Is & Is he...? & He is/ He's \\
\hline She & Is & Is she...? & She is/ She's \\
\hline It & Is & Is it...? & It is/ It's \\
\hline We & Are & Are you...? & We are/ We're \\
\hline You & Are & Are we...? & You are/ You're \\
(Plural) & & & Are they...? \\
\hline They & Are & They are/ They're \\
\hline
\end{tabular}




\section{Ejemplo,}

*Are you in class?

-Yes, I am. (Short)

-Yes, I am in class. (Long)

-No, I am not. (Short) or No, I'm not.

-No, I am not in class. (Long) or No, I'm not in class.

\section{Wh- Questions}

\section{What / Where /When / Who / Which/ How}

1. Where are you? (at school)

-I am at school

Let's practice.

1. Are they students?

2. Are the children in the garden? 
3. Are you in your house?

4. Is he a teacher?

Now practice with a partner considering all the options given:

1. How are you?

2. How is he?

3. How are they? 


\section{Reading}

\section{Cultural Awareness}

Most of us prefer to do business with people we like. And it should come as no surprise that the people we like tend to be like us. So whilst we may dispute the accuracy of cultural stereotypes it is generally agreed that good business relationships are built on cultural awareness. Across national frontiers 'nice guys' do more business than nasty ones. But what constitutes nice-guy behavior in a boardroom in Miami is not necessarily what they expect in Madrid.

\section{Say true or false}

1. People prefer to do business with unknown people. $T($ ) F ( )

2. Cultural awareness facilitates good business. $T$ ( ) F( )

3. Nice guys do less business than nasty ones. T ( ) $F($ )

4. Nice-guy behavior in a boardroom in Miami is not necessarily what they expect in Madrid. $T$ ( ) F( )

Write a short composition about a good business relationship in your country. 


\section{No Mercy's Song}

\section{Hello. How are you}

Go to youtube, listen to the song and fill in the blanks:

$$
\text { Hello, }
$$
you?

Would be Hello, where

I've been trying to reach you in vain

The emotion's written cross my face 
Like no rain drops in a sunny place

All the people that you knew before

Don't seem satisfied any more

I just contemplate the days we had

Now the sorrow here and I feel so sad

All this burning pain so hard to contain

All my memories on the nowhere train

Hello, how

?

Would be to again

Hello, where you?

I've been trying to reach in vain

Since you left I began to feel so sad

And my heart's been shaking with fear

I remember now the times we've had

And I think I wish you were here

And I think I wish you were here

Hello are you?

My imagination's driving me wild And I'm feeling like a silly child

I keep hoping and I search the sky

All I have now the tears I cry

I just contemplate the days we had 
Now the sorrows here and I feel so sad All this burning pain so hard to contain All my memories on the nowhere train Hello,

Would be to again where are $?$

I've been trying to reach you in vain I remember now the times we've had And I think I wish were here And I think I wish were here

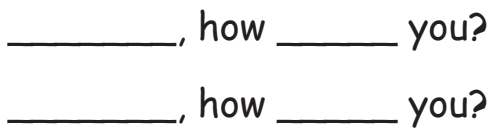

It's to you again

Hello, where

I've been trying to reach you in vain Hello, It's good to you again where ?

I've been trying to reach you in vain Hello, how you?

And I think I wish you were here Hello, are you? 



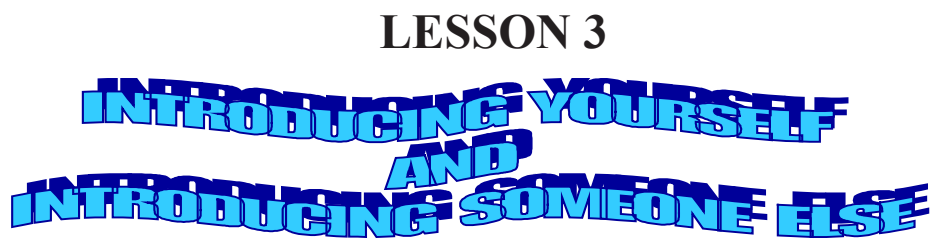

To introduce yourself

- I am Carolina García/ I'm Carolina García.

-My name is Carolina García/ My name's Carolina García.

To introduce someone else

-This is my mother/ my father/ my brother/ my sister/ my cousin/ my friend... This is Helen.

-I'd like you to meet my mother/my father/ my brother/ my sister/ my cousin/ my friend... I'd like you to meet Helen.

To be polite

-Nice to meet you

-Nice to meet you, too

-Glad to meet you

-Glad to meet you, too

- Pleased to meet you 
- Pleased to meet you, too

-It's a pleasure to meet you

-It's a pleasure to meet you, too

\section{Practice this dialogue:}

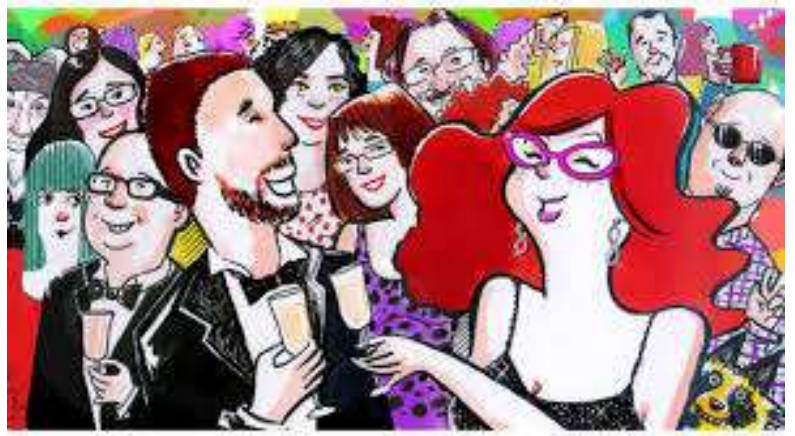

Peter: Hello.

Jane: Hi!

Peter: My name is Peter. What's your name?

Jane: My name is Jane. Nice to meet you.

Peter: It $>$ s a pleasure. This is a great party!

Jane: Yes, it is. Where are you from?

Peter: I $>m$ from Amsterdam.

Jane: Amsterdam? Are you German?

Peter: No, I $>$ m not German. I $>$ m Dutch. 
Jane: Oh, yourre Dutch. Sorry about that.

Peter: That s OK. Where are you from?

Jane: I $>\mathrm{m}$ from London, but I $>$ m not British.

Peter: No, what are you?

Jane: Well, my parents were Spanish, so I $>$ m Spanish, too.

Peter: That's very interesting. Spain is a beautiful country.

Jane: Thank you. It is a wonderful place.

\section{Formal Context:}

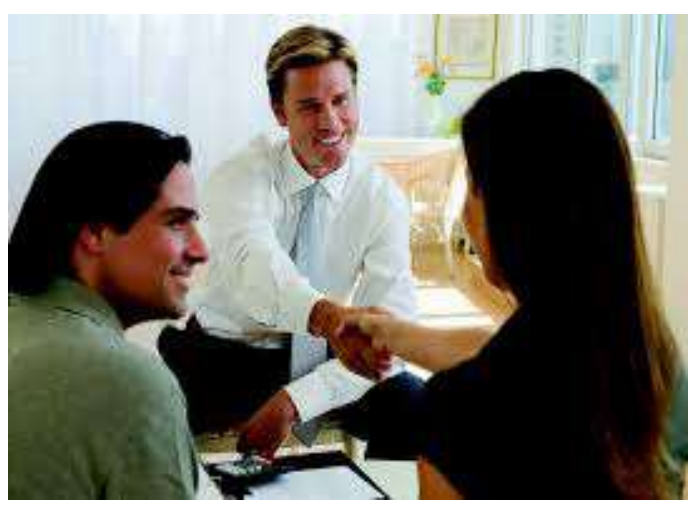

Ken: Peter, I'd like you to meet Mary.

Peter: It's a pleasure to meet you.

Mary: It's a pleasure to meet you too! 
Ken: Mary works for my company.

\section{Informal Context:}

Ken: Peter, this is Mary.

Peter: Hi. How are you?

Mary: Hello! Pleased to meet you.

Ken: Mary works for my company.

Taken from: https://www.thoughtco.com/beginner-dialogues-introducing-yourself-1210037

\section{Vocabulary}

-Check the following vocabulary:

Glad to meet you- It's a pleasure to meet you-Pleased to meet you- Nice to meet you

\section{-Nationalities:}

Country - Nationality - Language

- United Kingdom - British - English

- Scotland - Scottish - English / Gaelic

- Northern Ireland - Irish - English

- Wales - Welsh - English 
- Denmark - Danish - Danish

- Finland - Finnish - Finnish

- Norway - Norwegian - Norwegian

- Sweden-Swedish-Swedish

- Switzerland - Swiss - German / French / Italian

- Estonia-Estonian-Estonian

- Latvia-Latvian - Latvian

- Lithuania-Lithuanian - Lithuanian

- Austria-Austrian-Austrian

- Belgium - Belgian - French / Flemish

- France-French-French

- Germany-German-German

- Italy-Italian - Italian

- Netherlands - Dutch - Dutch

- United States - American - English

- Canada - Canadian - English / French

- Mexico - Mexican - Spanish

- Ukraine - Ukrainian - Ukrainian

- Russia-Russian-Russian

- Belarus - Belarusian - Belarusian

- Poland - Polish-Polish

- Czech Republic-Czech-Czech

- Slovakia-Slovak / Slovakian-Slovakian 
- Hungary - Hungarian - Hungarian

- Romania - Romanian - Romanian

- Bulgaria - Bulgarian - Bulgarian

- Greece-Greek - Greek

- Spain - Spanish - Spanish

Taken from: https://preply.com/en/blog/2015/07/28/ names-of-countries-and-nationalities-in-english/

\section{GRAMMAR}

\section{You can use:}

Where do you work?

I work in a company.

You work in a company.

He works in a company.

She works in a company.

It works in a company.

We work in a company.

You work in a company.

They work in a company.
Do you work in a company?

Yes, I do. I work in a company.

Does he work in a company?

Yes, he does. He works in a company.

Do they work in a company?

Yes, they do. They work in a company. 
YES YOU CAN！

\begin{tabular}{|l|l|l|l|l|l|}
\hline & $\begin{array}{l}\text { Subject } \\
\text { Pronoun }\end{array}$ & $\begin{array}{c}\text { Ob- } \\
\text { ject } \\
\text { Pro- } \\
\text { noun }\end{array}$ & $\begin{array}{c}\text { Possessive } \\
\text { Adjective } \\
\text { (Determiner) }\end{array}$ & $\begin{array}{c}\text { Pos- } \\
\text { sessive } \\
\text { Pronoun }\end{array}$ & $\begin{array}{c}\text { Reflexive } \\
\text { or Inten- } \\
\text { sive Pro- } \\
\text { noun }\end{array}$ \\
\hline $\begin{array}{l}\text { 1st person } \\
\text { singular }\end{array}$ & I & me & My & mine & myself \\
\hline $\begin{array}{l}\text { 2nd person } \\
\text { singular }\end{array}$ & you & you & Your & yours & yourself \\
\hline $\begin{array}{l}\text { 3rd person } \\
\text { singular, } \\
\text { male he }\end{array}$ & him & His & his & himself \\
\hline $\begin{array}{l}\text { 3rd person } \\
\text { singular, fe- } \\
\text { male }\end{array}$ & she & her & Her & hers & herself \\
\hline $\begin{array}{l}\text { 3rd person } \\
\text { singular, } \\
\text { neutral }\end{array}$ & it & it & Its & Their & themselves \\
\hline $\begin{array}{l}\text { 1st person } \\
\text { plural }\end{array}$ & we & us & Our & ours & ourselves \\
\hline $\begin{array}{l}\text { 2nd person } \\
\text { plural }\end{array}$ & you & you & Your & yours & yourselves \\
\hline $\begin{array}{l}\text { 3rd person } \\
\text { plural }\end{array}$ & they & them & Their & theirs \\
\hline
\end{tabular}


Now practice with a partner considering all the options given:

1. What's your name?

2. Do you work in a company?

3. Where do you work?

\section{Reading}

\section{Mary's family}

Mary is ten years old. She is from Dorset. Her hair is long and brown. She has got brown eyes. She has got a cat and a dog. Their names are Pat and Fluffy. Pat, the dog has got a small house in the garden. Mary's cat, Fluffy is 3 years old.

Mary's mother is Jane. She is a teacher. She's thirtysix years old. Her husband is Nick. He is thirty-eight. He's a bus driver. He has got brown hair and blue eyes. Jane's hair is blonde and her eyes are brown. They have got three children Mary, Sean and Peter.

Sean is six and Peter is twelve years old. The children 
are pupils. Sean's hair is blonde, Peter's hair is brown. The boys have got blue eyes.

Jane hasn't got a pet. She has a friend. Her name is Laura. Nick has got a horse. Its name is lightning. Nick's friends are bus drivers. They are Tom, Charles and John.Peter's pet is a hamster. Its name is Tiny. She is so small. Sean has got a goldfish. Its name's Goldie. Peter and Sean have got four friends. Peter's friends are James and Doug. Brian and Adam are Sean's friends. Mary's friends are Maggie and April. 





\section{YES YOU CAN !}

\section{LESSON 4}
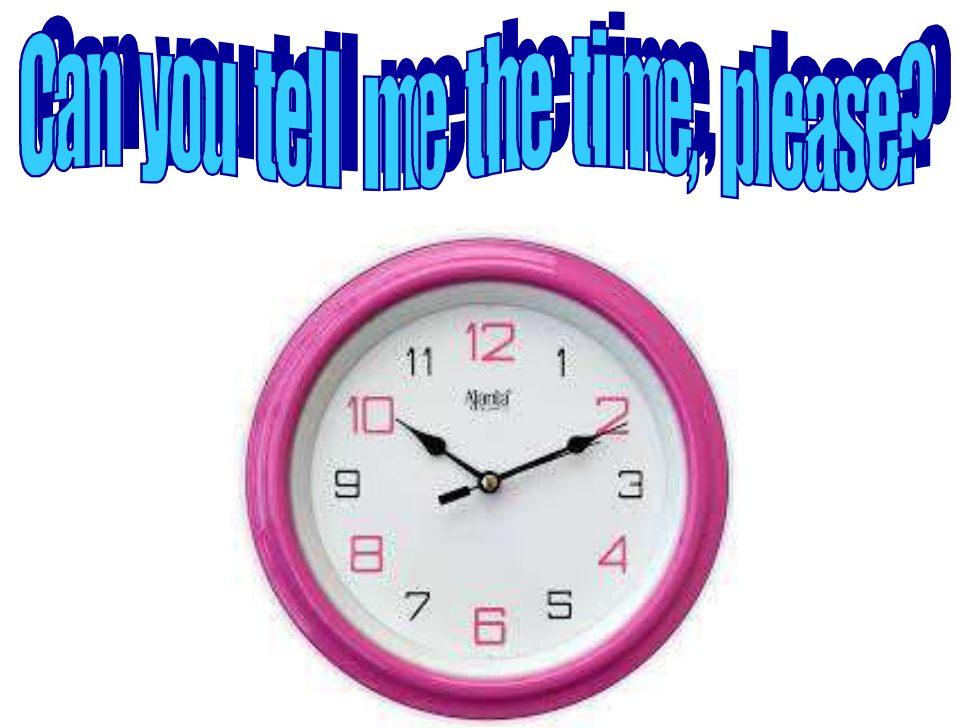

To tell the time, you can use different ways such as the following:

- What time is it?

-It's 10: 10.

-It's ten, ten.

-It's 10 past ten. 
These are some of the options:

-A quarter past.

- It's a quarter past 4.

- Half past.

- It's half past 9.

- A quarter to

- It's a quarter to 12 .

- $A M / P M$

- It's 7:50 AM.

- It's 11:20 PM.

- Noon.

- Midnight.

See this conversation:

Anne: John, What time should I go to school?

John: At 9 o' clock.

Anne: What time is it, please?

John: It's three fifteen.

Anne: What time does the teacher arrive?

John: At eight thirty. 
Anne: Ok. I'll be there on time.

Now, answer the questions:

a. What time should Anne and John go to class?

b. What time is the teacher at school?

c. What time are John and Anne talking?

\section{Vocabulary}

Common questions:

-What time...?

-When...?

-What time is it?

-What is the time? 


\section{Other questions:}

- What time does the flight to Europe leave?

- When does your sister arrive?

- When does the class begin?

Months of the year:

January

February

March

April

May

June

July

August

September

October

November

December

Days of the Week

\begin{tabular}{l} 
Monday \\
\hline Tuesday \\
\hline Wednesday \\
\hline Thursday \\
\hline Friday \\
\hline Saturday \\
\hline Sunday
\end{tabular}




\section{The seasons of the year}

1. Spring

2. Summer

3. Fall or Autumn

4. Winter

\section{Let's practice}

1. What day is today?

- Today is Monday.

- It's Monday.

2. What month are we in?/ What month is it?

- In July. Today is the third/ It's July.

3. What season are we in? / What season is it?

- In summer/ It's summer.

Meteorological

\begin{tabular}{|l|l|l|}
\hline $\begin{array}{c}\text { Northern hemisphe- } \\
\text { re }\end{array}$ & $\begin{array}{l}\text { Southern hemis- } \\
\text { phere }\end{array}$ & \multicolumn{1}{|c|}{ End date } \\
\hline Winter & Summer & 28 February \\
\hline Spring & Autumn & 31 May \\
\hline Summer & Winter & 31 August \\
\hline Autumn & Spring & 30 November \\
\hline
\end{tabular}

Cardinal Numbers:

\begin{tabular}{|l|l|}
\hline Zero & 0 \\
\hline One & 1 \\
\hline
\end{tabular}




\begin{tabular}{|l|l|}
\hline Two & 2 \\
\hline Three & 3 \\
\hline Four & 4 \\
\hline Five & 5 \\
\hline Six & 6 \\
\hline Seven & 7 \\
\hline Eight & 8 \\
\hline Nine & 9 \\
\hline Ten & 10 \\
\hline Eleven & 11 \\
\hline Twelve & 12 \\
\hline Thirteen & 13 \\
\hline Fourteen & 14 \\
\hline Fifteen & 15 \\
\hline Sixteen & 16 \\
\hline Seventeen & 17 \\
\hline Eighteen & 18 \\
\hline Nineteen & 19 \\
\hline Twenty & 20 \\
\hline twenty-one & 21 \\
\hline twenty-two & 22 \\
\hline twenty-... & 2 \\
\hline Thirty & 30 \\
\hline thirty-one & 31 \\
\hline thirty-two & 32 \\
\hline thirty-... & 3 \\
\hline Forty & 40 \\
\hline & \\
\hline & 30 \\
\hline
\end{tabular}




\begin{tabular}{|l|l|}
\hline forty-one & 41 \\
\hline forty-two & 42 \\
\hline forty-... & 4 \\
\hline Fifty & 50 \\
\hline fifty-one & 51 \\
\hline fifty-two & 52 \\
\hline fifty-... & 5 \\
\hline Sixty & 60 \\
\hline sixty-one & 61 \\
\hline sixty-two & 62 \\
\hline sixty-... & 6 \\
\hline Seventy & 70 \\
\hline seventy-one & 71 \\
\hline seventy-two & 72 \\
\hline seventy-... & 7 \\
\hline Eighty & 80 \\
\hline eighty-one & 81 \\
\hline eighty-two & 82 \\
\hline eighty-... & 8 \\
\hline Ninety & 90 \\
\hline ninety-one & 91 \\
\hline ninety-two & 92 \\
\hline ninety-... & 9 \\
\hline one hundred & 100 \\
\hline one hundred and one & 101 \\
\hline one hundred and two & 102 \\
\hline one hundred and... & 1 \\
\hline
\end{tabular}




\begin{tabular}{|l|l|}
\hline two hundred & 200 \\
\hline three hundred & 300 \\
\hline nine hundred and ninety-nine & 999 \\
\hline one thousand & 1000 \\
\hline two thousand & 2000 \\
\hline three thousand & 3000 \\
\hline ... thousand & _o00 \\
\hline $\begin{array}{l}\text { one thousand, two hundred and } \\
\text { thirty-four }\end{array}$ & 1234 \\
\hline $\begin{array}{l}\text { nine thousand, nine hundred and } \\
\text { ninety-nine }\end{array}$ & 9999 \\
\hline ten thousand & 10000 \\
\hline one million & 1000000 \\
\hline two million & 2000000 \\
\hline ten million & 10000000 \\
\hline one billion & $\begin{array}{l}1000 \\
\text { (mil millones) }\end{array}$ \\
\hline one trillion & $\begin{array}{l}1000000 \\
000\end{array}$ \\
\hline
\end{tabular}

Ordinal Numbers: 


\section{Ordinal Numbers}

Ordinal number; a number defining the position of something in a series, such as 'first', 'second', or 'third'. Ordinal numbers are used as adjectives, nouns, and pronouns.

\begin{tabular}{|c|c|c|c|c|c|c|c|}
\hline st & First & 11 th & Eleventh & $21 \mathrm{st}$ & Twenty-first & $31 s t$ & Thirty-first \\
\hline 2nd & Second & 12th & Twelfth & 22nd & Twenty-second & 40th & Fortieth \\
\hline Ird & Third & 13th & Thirteenth & 23rd & Twenty-third & 50th & Fiftieth \\
\hline 4th & Fourth & 14th & Fourteenth & 24th & Twenty-fourth & 60th & Sixtieth \\
\hline sth & Fifth & 15 th & Fifteenth & 25th & Twenty-fifth & 70th & Seventieth \\
\hline th & Sixth & 16th & Sixteenth & 26th & Twenty-sixth & 80th & Eightieth \\
\hline h & Seventh & 17 th & Seventeenth & 27 th & Twenty-seventh & 90th & Ninetieth \\
\hline 8th & Eighth & 18th & Eighteenth & 28th & Twenty-eighth & 100th & One hundredth \\
\hline 9 th & Ninth & 19th & Nineteenth & 29th & Twenty-nineth & 1,000 th & One thousandth \\
\hline th & Tenth & 20th & Twentieth & 30th & Thirtieth & $1,000,000$ th & One millionth \\
\hline
\end{tabular}

Practice these questions and answers:

1. What day is today?

-Today is Monday/ It's Monday.

2. What's today's date?/ What's the date today?

-It's January $27^{\text {th }}$.

3. When is your birthday?

-It's in August/ It's on August $21^{\text {st }}$.

4. When were you born?

- I was born in 1970.

5. Where were you born?

- I was born in Spain. 
Now, practice with a partner and then act it out:

1. What day is today?

2. What's today's date?

3. When is your birthday?

4. When were you born?

5. Where were you born?

Calendar in English

\begin{tabular}{|l|l|l|l|l|l|l|}
\hline Sun & Mon & Tue & Wed & Thu & Fri & Sat \\
\hline 1 & 2 & 3 & 4 & 5 & 6 & 7 \\
\hline 8 & 9 & 10 & 11 & 12 & 13 & 14 \\
\hline 15 & 16 & 17 & 18 & 19 & 20 & 21 \\
\hline 22 & 23 & 24 & 25 & 26 & 27 & 28 \\
\hline 29 & 30 & 31 & & & & \\
\hline
\end{tabular}




\section{GRAMMAR}

\section{You can use:}

What time is it?

-It's 4 am

$-9: 30 \mathrm{am}$

-11 o'clock pm

In/ On

You use "in" when saying only the month:

In August

You use "on" when saying the month and the date:

On August 21st.

The verb to be in past

\begin{tabular}{|l|l|l|l|}
\hline \multicolumn{1}{|c|}{$\begin{array}{c}\text { Personal } \\
\text { Pronouns }\end{array}$} & \multicolumn{1}{c|}{$\begin{array}{c}\text { Verb to } \\
\text { be in past }\end{array}$} & \multicolumn{1}{|c|}{ Questions } & \multicolumn{1}{|c|}{ Answers } \\
\hline I & was & Were you...? & I was \\
\hline You (singular) & were & Was I...? & You were \\
\hline He & was & Was he...? & He was \\
\hline She & was & Was she...? & She was \\
\hline It & was & Was it...? & It was \\
\hline We & were & Were you...? & We were \\
\hline You (Plural) & were & Were we...? & You were \\
\hline They & were & Were they...? & They were \\
\hline
\end{tabular}




\section{Ejemplo, \\ *Were you in class?}

-Yes, I was. (Short)

-Yes, I was in class. (Long)

-No, I was not. (Short)

-No, I was not in class. (Long)

\section{Wh- Questions}

\section{What / Where /When / Who / Which/ How}

1. Where were you? (at school)

-I was at school

Let's practice.

1. Were they in the garage?

2. Were the children in the garden?

3. Were you in your house?

4. Was he in the church? 
Now practice with a partner considering all the options given:

1. What's the time?

2. What time is it, please?

\section{Reading}

Tips for understanding and remembering what you read...

- Before you read, look at the title, pictures, and headings. Can you guess the topic and main ideas? This prepares your mind to learn.

- Underline or highlight important ideas.

- Draw pictures and diagrams about important ideas.

- Write notes about the text. Read a paragraph. Cover the paragraph and tell yourself what it was about.

- Read groups of two or three words together. Groups of two or three words have more meaning than single words. 
- If you don't know a word, say the word out loud. Maybe you will know the meaning if you hear it.

- If you don't know a word, read the sentence it comes from and try to guess the meaning.

- Remember that you don't always need to understand every word.

Answer these questions according to the text above:

1. What's the text about?

2. What do you do with the important ideas?

3. How can the groups of words help you?

4. How can you guess the meaning of a sentence? 


\section{A great summer vacation}

I just returned from the greatest summer vacation! It was so fantastic, I never wanted it to end. I spent eight days in Paris, France. My best friends, Henry and Steve, went with me. We had a beautiful hotel room in the Latin Quarter, and it wasn't even expensive. We had a balcony with a wonderful view.

We visited many famous tourist places. My favorite was the Louvre, a well-known museum. I was always interested in art, so that was a special treat for me. The museum is so huge, you could spend weeks there. Henry got tired walking around the museum and said "Enough! I need to take a break and rest."

We took lots of breaks and sat in cafes along the river Seine. The French food we ate was delicious.

The wines were tasty, too. Steve's favorite part of the vacation was the hotel breakfast. He said he would be happy if he could eat croissants like those forever. We had so much fun that we're already talking about our next vacation!

Taken from: lingua.com 
Say true or false:

1. The author spent ten days in Paris, France.

$T() F($ )

2. The hotel was cheap. T( )F( )

3. We took lots of breaks and sat in cafes. T ( ) $F($ )

4. They like the wines. $T($ ) F ( )

Answer these questions:

1. How was the summer vacation?

2. Was it expensive?

3. Were the wines sour?

4. How was the French food? 


\section{YES YOU CAN !}

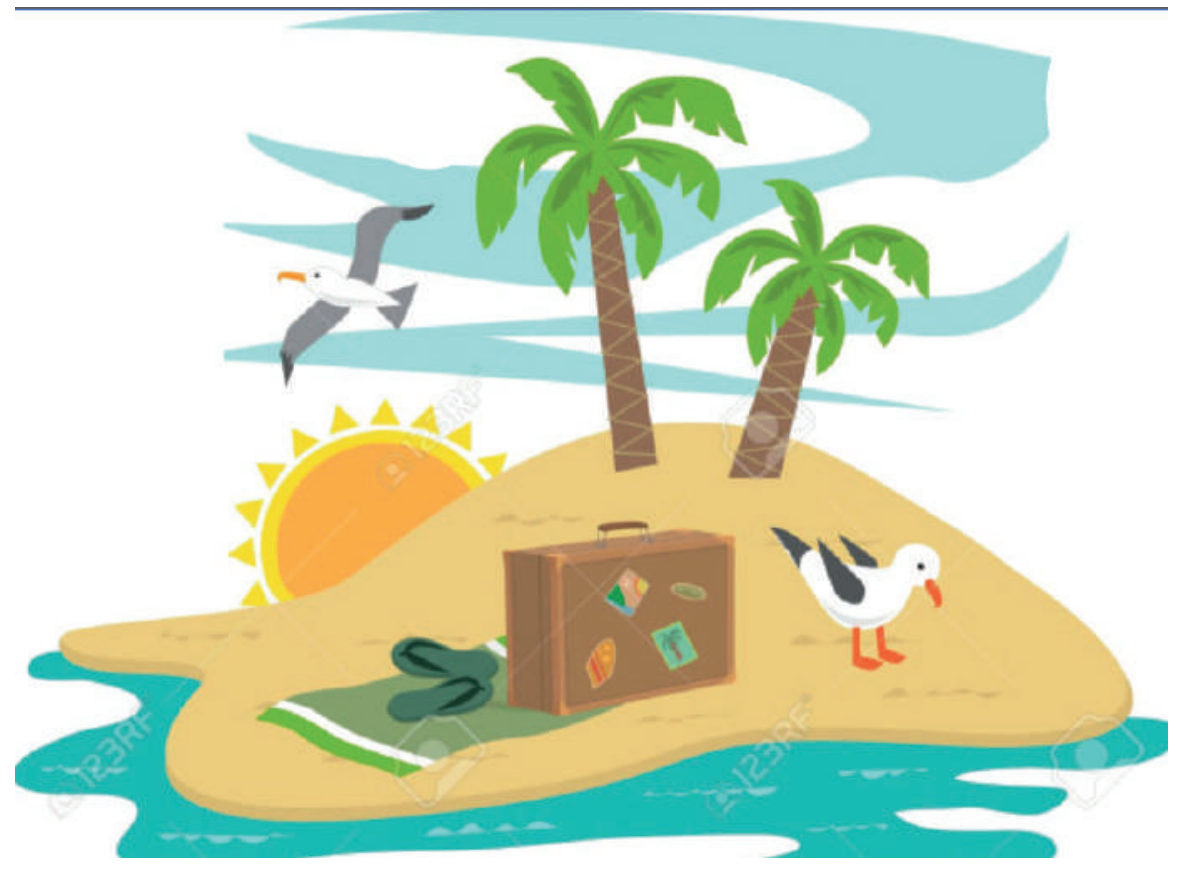







\section{LESSON 5}
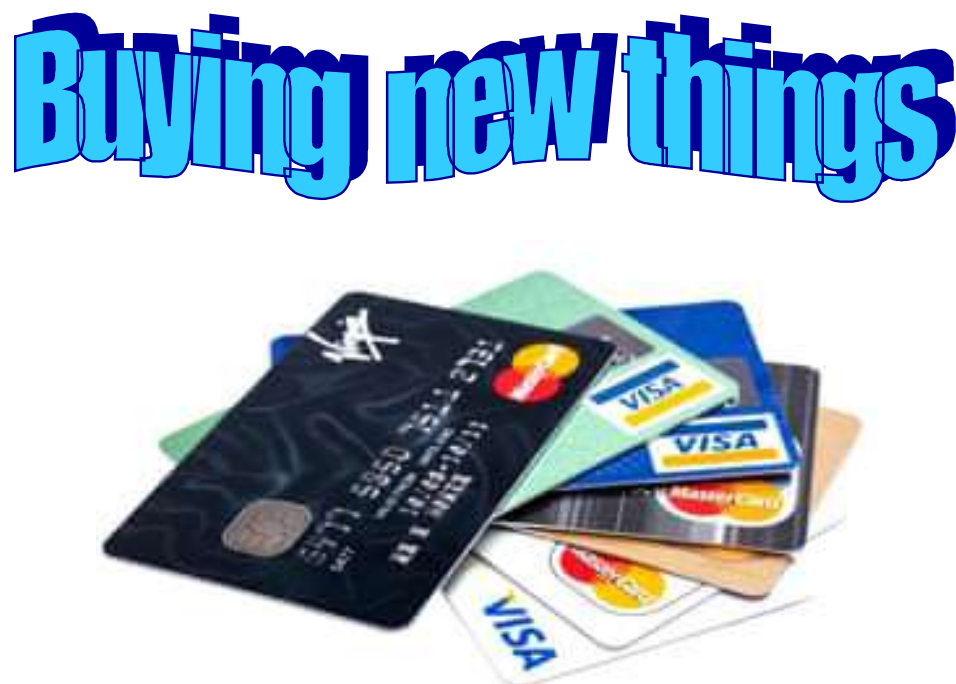

\section{Let's go shopping:}

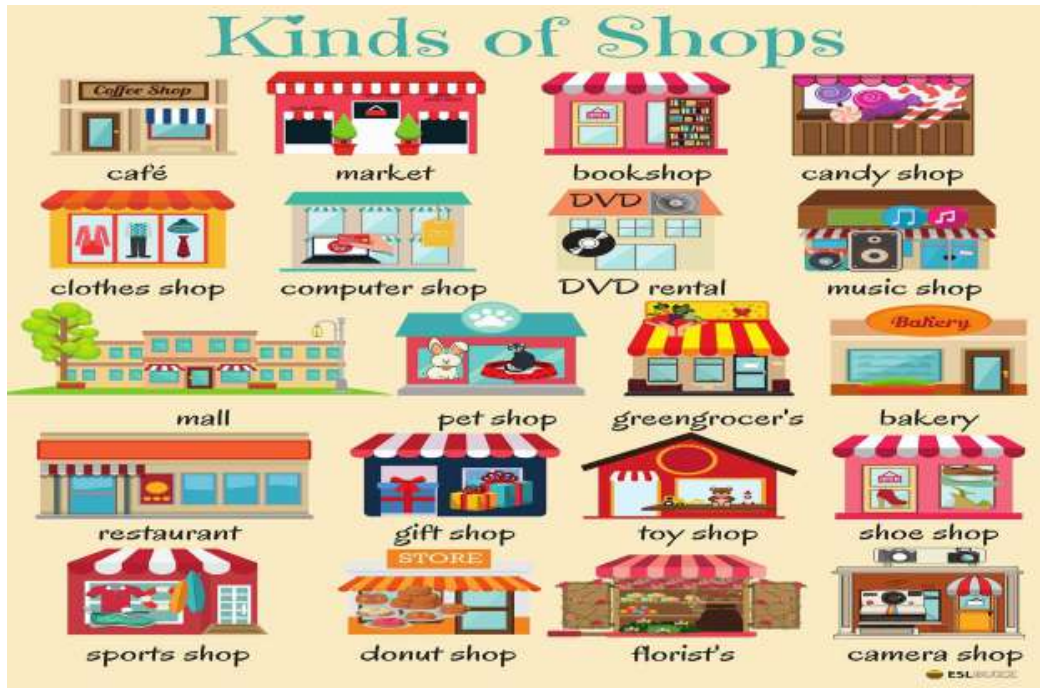




\section{Common questions:}

-Where would you like to go shopping?

-Where do you want to go shopping?

-Would you like to go shopping?

-What would you like you buy?

-How much is it?

-How much does it cost?

Common expressions:

-Let's go shopping.

-Do the shopping.

-It's \$2.000 (Two thousand dollars)

-On sale

- I can't afford it.

- In stock/out of stock. ...

- It costs a fortune! ... 
- It costs an arm and a leg!

- Can you give me a discount, please?

\section{Dialogues to practice}

Dialogue 1

\section{Cash or Charge?}

A: What do you think?

B: It looks great.

A: I would like to purchase it.

B: Will this be cash or charge?

A: Here, take my credit card.

B: Just sign here, please.

A: Sure. Here you go.

B: Here's your receipt. Have a nice day.

Check this page for the pronunciation: https://www. eslfast.com/robot/topics/shop/1shop03.htm

Answer these questions according to the dialogue:

1. What's the customer's opinion about the product? 
2. Is the person going to pay by cash or charge?

Dialogue 2

\section{To return a product}

A: I'd like to return this radio.

B: All right. Do you have the receipt?

A: Here it is.

B: May I ask why you're returning the radio?

A: It does not work very well.

B: Would you like to exchange it?

A: No. I'd just like a refund.

B: Certainly. This will take only a few seconds.

Check this page for the pronunciation: https://www. 
eslfast.com/robot/topics/shop/1shop04.htm

Answer these questions according to the dialogue:

1. What's the person going to return?

2. What happens to it?

3. Is the customer going to exchange it?

Dialogue 3

Looking for a beautiful gift

A: Can you help me pick out a gift for my niece?

B: Most normal little girls go wild over Barbie dolls.

A: That sounds good. Let me see one.

B: Here's the latest model Digital Barbie. 
A: She's nice. How much is she?

B: Why, she's only $\$ 29.95$.

A: That's reasonable. I'll take it.

B: Excellent. Would you like anything else?

$A$ : No, thank you.

B: The total will be $\$ 32.42$. Will that be cash?

A: Cash will be fine.

B: Here's your change. Thank you for shopping with us.

Check this page for the pronunciation: https://www. eslfast.com/robot/topics/shop/1shop09.htm

Answer these questions according to the dialogue:

1. What do little girls prefer? 
2. What is the customer going to buy?

3. How much is it?

4. Is the customer going to pay in chash?

\section{Vocabulary}

Common words:

- Cheap

-Expensive

- Cash

-Charge

-Pay

-Customer

-Seller 


\section{GRAMMAR}

\section{You can use:}

Third person singular:

How much does it cost?

-It's \$2.000

-It costs $\$ 2.000$

Third person plural:

How much do they cost?

They're $\$ 2.000$

They cost 2.000

\section{Be going to}

What are you going to...? I am going to.../ I'm going to...

Where is he going to...? He is going to.../ He's going to...

When is she going to...? She is going to.../ She's going to...

Where is it going to...? It is going to.../ It's going to... What are you going to...? We are going to.../ We're going to...

What are they going to...? They are going to.../ They're going to...

\section{Exercise}

Practice with a partner with all the options given.

(Practice with real situations) 


\section{Now practice with a partner}

1. How much does it cost?

2. How much do they cost?

\section{Reading}

\section{Public Libraries}

If you live in Winnipeg, you can borrow books for free from any branch of the Winnipeg Public Library. If you live outside of Winnipeg and want to borrow resources from the Winnipeg Public Library, you can get a Non- Resident Card for an annual fee. Some rural municipalities will give some or all of this fee back to you.

The library has a variety of materials you can borrow including books, audio books, magazines, CDs, videos, and DVDs. Some branches have books in different languages.

\section{At the Library}

You can search for a book on the computer terminals or ask the library staff for help. Some phras- 


\section{YES YOU CAN！}

es you can use are:

"I'm looking for books about learning English. Can you help me?"

"Where are the books for learning English?"

"Can you help me find the English study books?"

If the book you need is not available at your local library, you can have it sent from another library.

"I'd like to order a book from another library."

"How do I place an inter-library loan?"

Say true or false:

1. The library has no many materials. $T() F()$

2. You can search for a book on the computer terminals. $\mathrm{T}(\mathrm{)} F(\mathrm{)}$

3. If the book you need is not available at your local library, you cannot have it sent from another library. T ( ) F ( )

4. In Winnipeg, you can borrow books for free. $\mathrm{T}(\mathrm{f}) \mathrm{F}(\mathrm{)}$ 
Answer the following questions:

1. Can you borrow books for free?

2. Where can you borrow books for free?

3. How can you do if you live outside of Winnipeg?

4. Which phrases you can use to ask for help in a library? 




\section{LESSON 6}
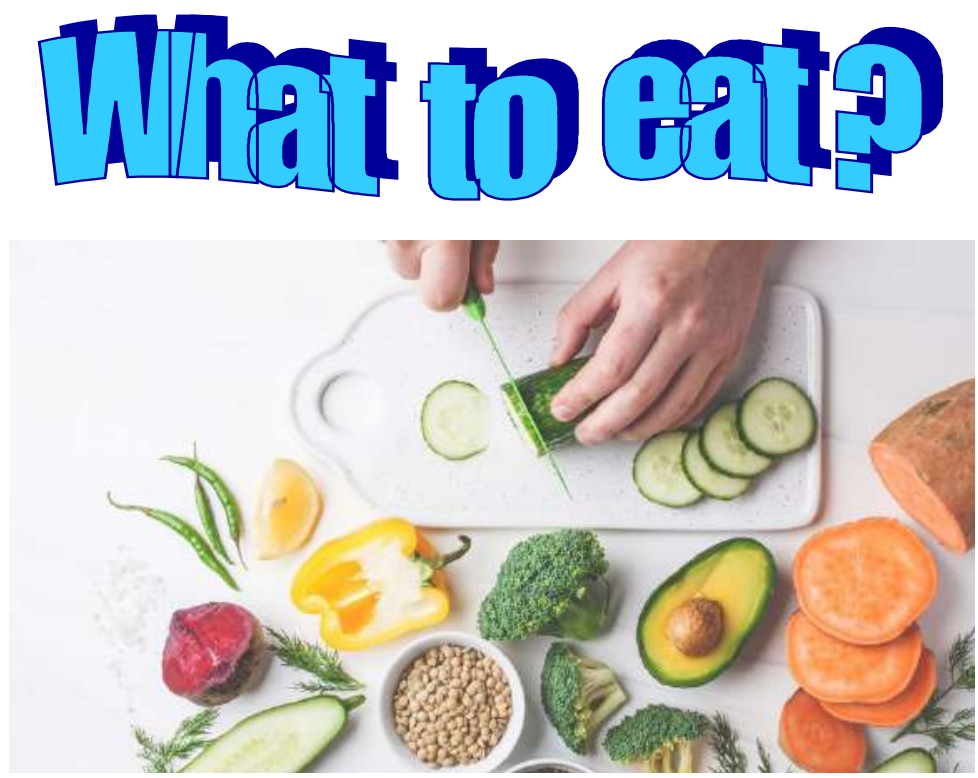

Let's go to eat:

\section{Vegetables}

A: What vegetable do you prefer?

B: I prefer the lettuce. What about you?

A: I like broccoli.

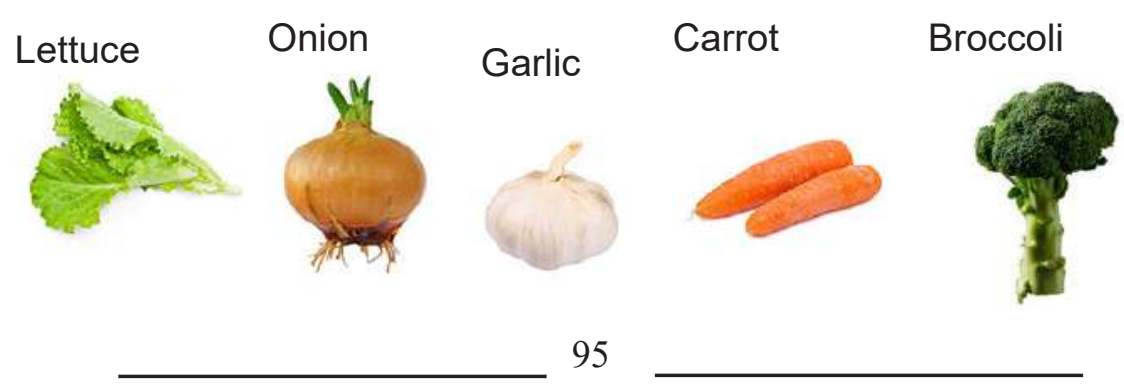




\section{Common questions:}

-How's your food?

-What do you prefer pizza or hamburger?

-Do you like coffee?

-How does it taste?

Common expressions:

-This curry is very spicy

-Put vinegar in it.

-I don't like the salty food.

-I like apples.

-It's too chewy.

-You should cook it for too long.

-Let's cook a pizza.

In a restaurant:

-How is the meat?

-Could I have the menu, please?

-Could you bring the check, please? / I'd like the check, please.

-What would you recommend?

-I'll have an appetizer. 
-I would like dessert.

-May I have the bill?

Taken from: https://www.thoughtco.com/beginner-dialogues-at-a-restaurant-1210039

\section{Dialogues to practice}

Dialogue 1

Waitperson: Hi. How are you doing this afternoon?

Customer (you): Fine, thank you. Can I see a menu, please?

Waitperson: Certainly, here you are.

Customer: Thank you. What's today's special?

Waitperson: Grilled tuna and cheese on rye.

Customer: That sounds good. I'll have that.

Waitperson: Would you like something to drink?

Customer: Yes, I'd like a coke.

Waitperson: Thank you. (returning with the food) Here you are. Enjoy your meal! 
Customer: Thank you.

Waitperson: Can I get you anything else?

Customer: No thanks. I'd like the check, please.

Waitperson: That'll be $\$ 14.95$.

Customer: Here you are. Keep the change!

Waitperson: Thank you! Have a good day!

Customer: Goodbye.

\section{Dialogue 2}

A - May I take your order?

B - Yes. I'd like the chicken and a side order of corn.

A - And what would you like to drink?

B - I'd like a cup of coffee, please.

A - And what would you like to order?

C - I'll take the spaghetti and a salad.

A - What would you like to drink?

C-Just water, please. 


\section{(after the meal)}

A - Would you like something for dessert?

B - Yes, I'll have the cake, please. Would you like something?

C - No thanks. I'm full.

(after dessert)

B - Could we have the check, please?

A - Yes, here it is.

B - Hmmm. \$23.55. Here you are.

A - Thank you. Come again.

B - Thank you. Goodbye.

You can check the pronunciation here: https://www. passporttoenglish.com/Beginning-English/Lesson7/Dialog.html 
VOCABULARY

Common words:

- Spicy

- Sour

- Bitter

-Salty

-Sweet

- Tasty

-Disgusting

-Yummy

-Mouth-watering

-Scrumptious

-Rich

-Decadent

- Tender

-Juicy

-Crisp

-Fresh

-Dessert 
-Revolting

-Bland

-Tasteless

-Burnt

-Overdone

\section{Food}

\section{Vegetables}

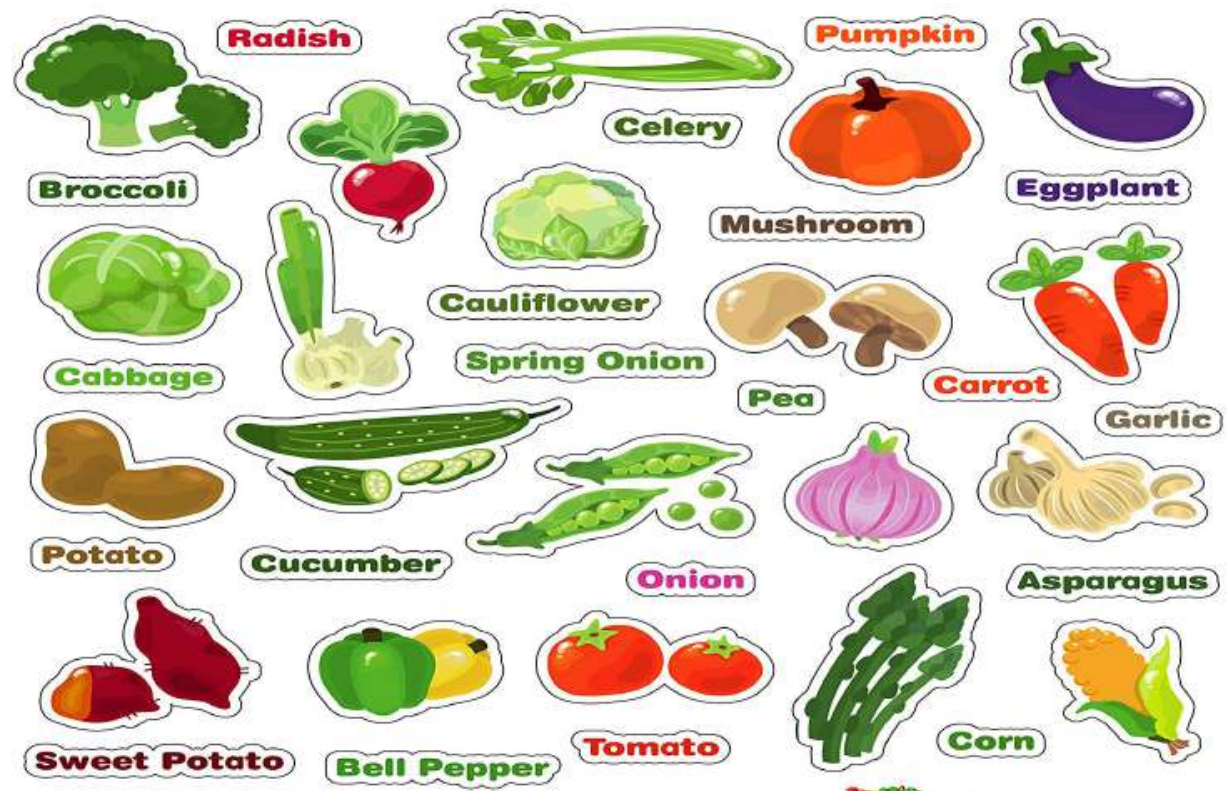




\section{YES YOU CAN！}

\section{Fruits}

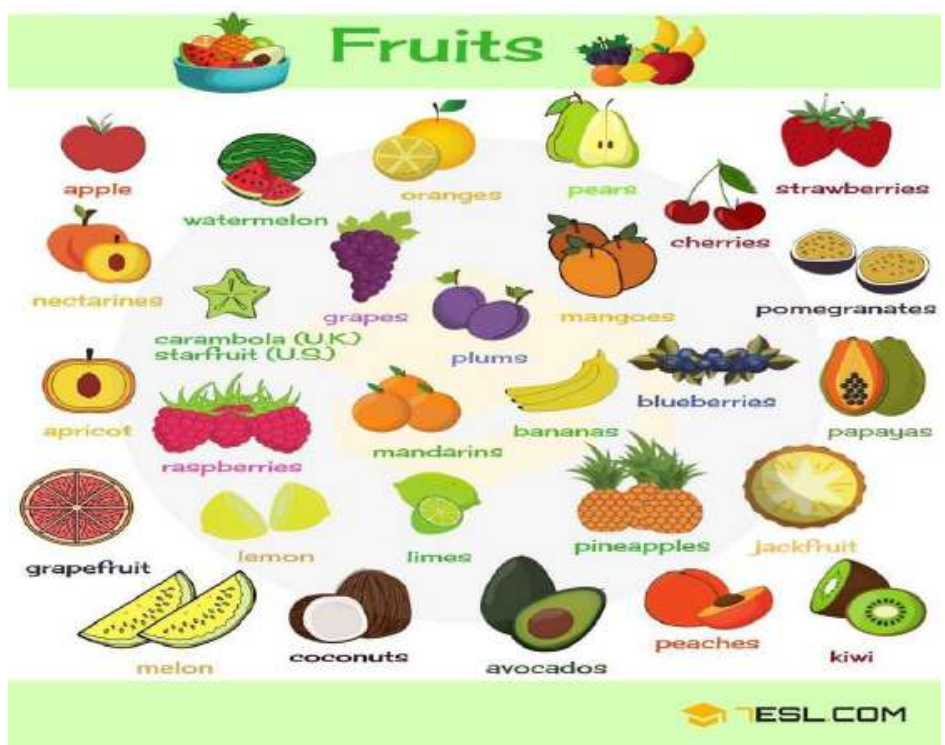

For Breakfast

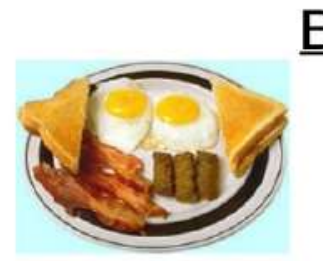

Eggs, toast, sausage \& bacon

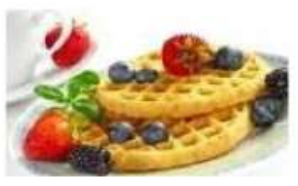

Waffles topped with fruit

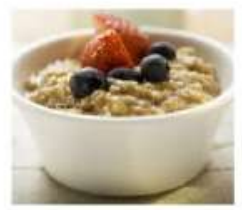

Oatmeal

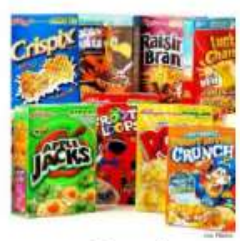

Cereal

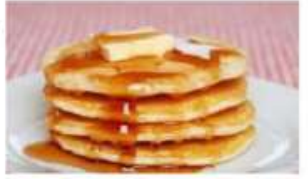

Pancakes \& maple syrup

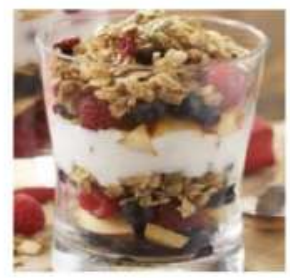

Yogurt \& granola 


\section{For Lunch}

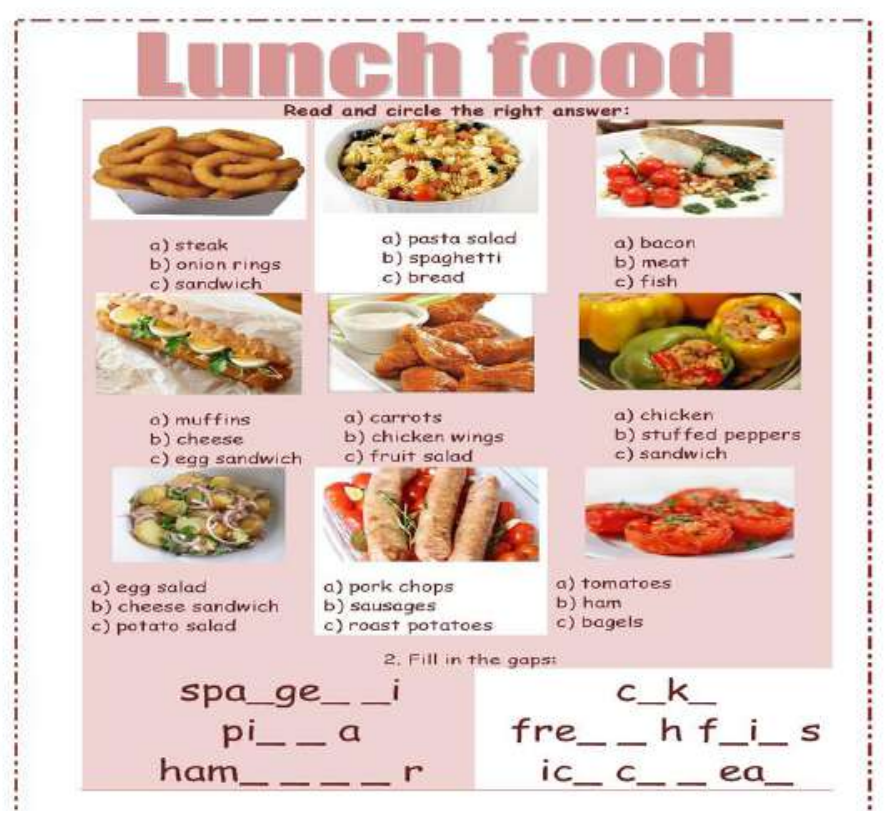

\section{For Dinner}

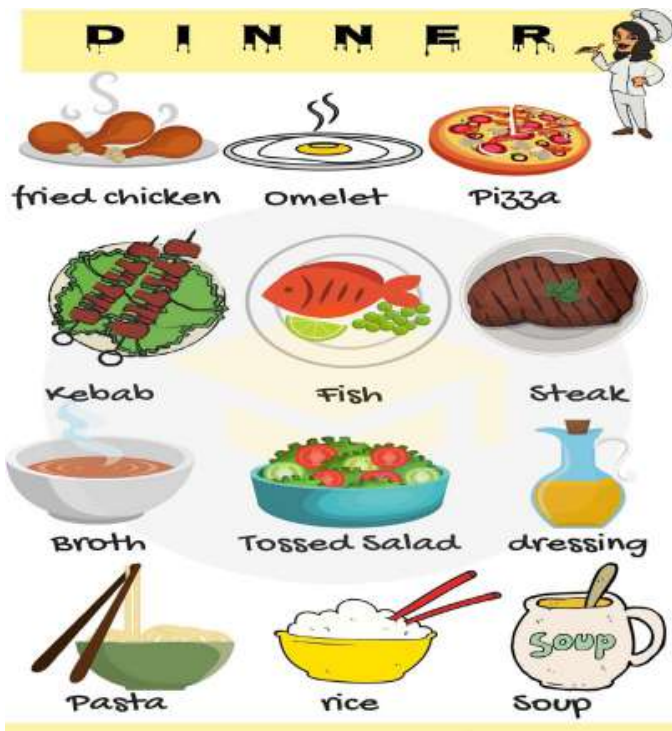




\section{GRAMMAR}

\section{You can use:}

Countable and Uncountable Nouns:

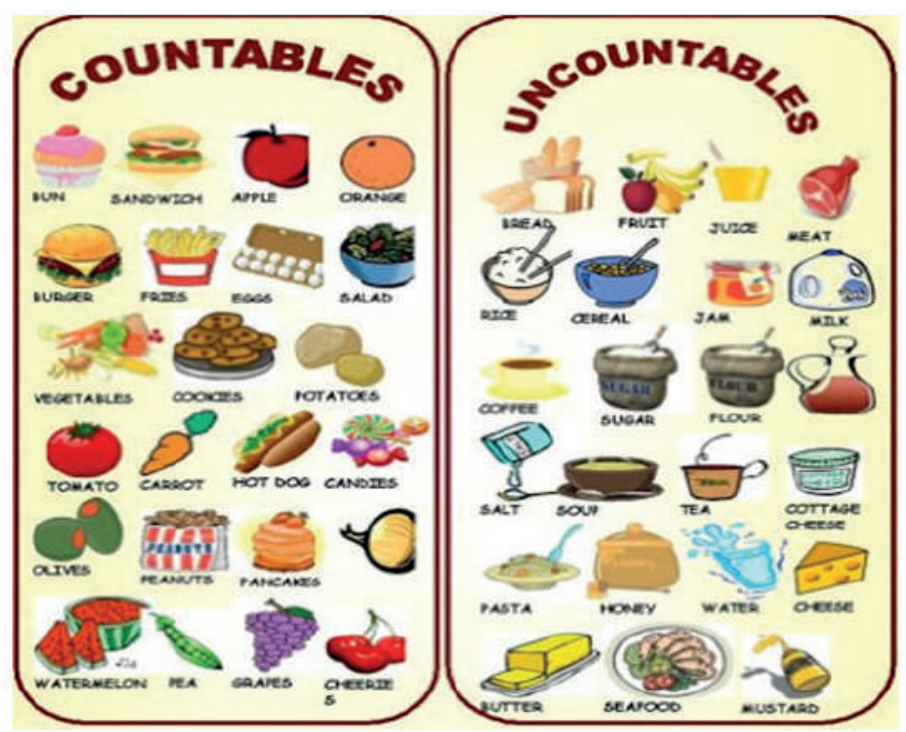

What is a countable noun?

It refers to something that can be counted.

What is a countable noun?

It refers to something that cannot be counted. They have not regularly plural form. 
For countable nouns, you use:

A/an, any, some or how many with countable nouns.

For uncountable nouns:

Some, any or how much with uncountable nouns.

Some examples,

-There are a lot of grapes but there aren't many oranges.

There's lots of juice but there isn't much water.

- Do you want some chocolate?

-Can we have more eggs, please?

Is there any salt?

How much apple juice is there?

There's some juice in the fridge.

There isn't any coffee.

List of some uncountable nouns:

- tea

- sugar

- water 
- air

- rice

-knowledge

- beauty

- anger

- fear

- love

- money

- research

- safety

- evidence

List of some countable nouns:

- Horse

- Man

- Chair

- Book 
Now practice with a partner:

How much juice do you have?

1. How much juice do you have?

2. How many oranges would you like?

\section{Talking about food}

\section{What Do You Usually Eat?}

This is one of the most common questions that people ask one another and it's always interesting to hear everyone's answers.

Fast food

Fast food is served very quickly over the counter at restaurants such as McDonald's or Chick-fil-A. It's usually a meal with hamburgers or sandwiches, French fries and soda.

When I'm busy with school, I usually end up eating fast food. 


\section{Home-cooked meal}

A home-cooked meal is what many of us would like to have waiting for us when we get home from school or work. This is a fresh meal that's made and eaten at home.

Whenever I get home early from work, I make myself a nice home-cooked meal.

\section{One-pot meal}

A one-pot meal means exactly what it says. You cook all of your ingredients (food items) like meat and vegetables in one pot and you're ready to eat.

If I'm too tired to cook, I just make a quick and easy one-pot meal.

\section{Dessert}

Dessert is a sweet dish, like pastry or ice cream, that's served and eaten at the end of a meal.

My grandma makes amazing cookies, cakes and pies. I 
always look forward to dessert when I go to her house.

Taken from: https://www. fluentu.com/blog/english/ talking-about-food-in-english/

Say true or false:

1. McDonald's sells fast food. T ( ) F ( )

2. A home-cooked meal is the one we eat for dinner. $\mathrm{T}(\mathrm{F}$ ( )

3. Dessert is a sweet dish. T( )F( )

4. grandma makes wonderful cookies $T(） F($ )

Answer the following questions:

1. Is MCDonald's a good option to eat?

2. What is an easy one-pot meal?

3. What is a home cooked-meal?

4. What's a dessert? 




\section{LESSON 7}
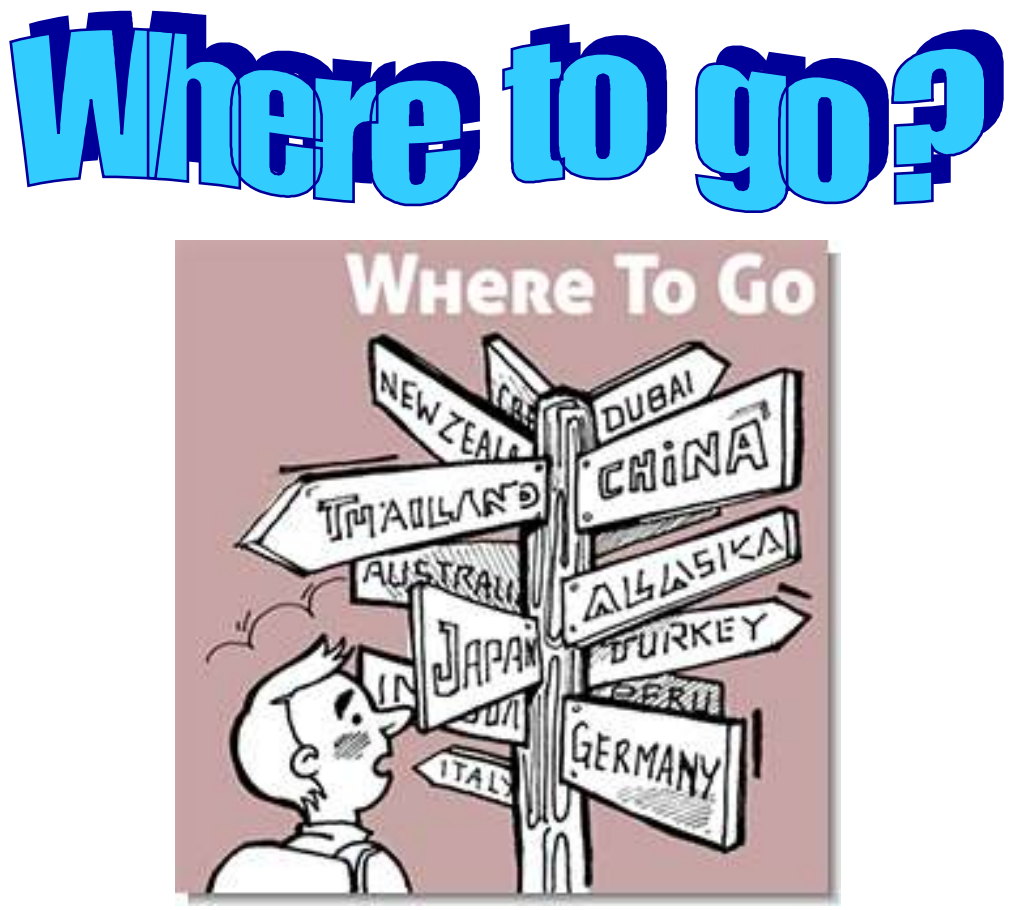

Let's plan our trip

-Where would you like to travel?

- I would like to travel to Germany.

Common expressions:

-What time is my flight?

-What airline am I flying?

-Where is my gate?

-Do you have a map? 
-Are meals included?

-I would like to go to Europe

-How do I call for room service?

-Where can I find a grocery store?

-Where is the bank?

-How do you get to $?$

-How far is it to ?

See this Map:

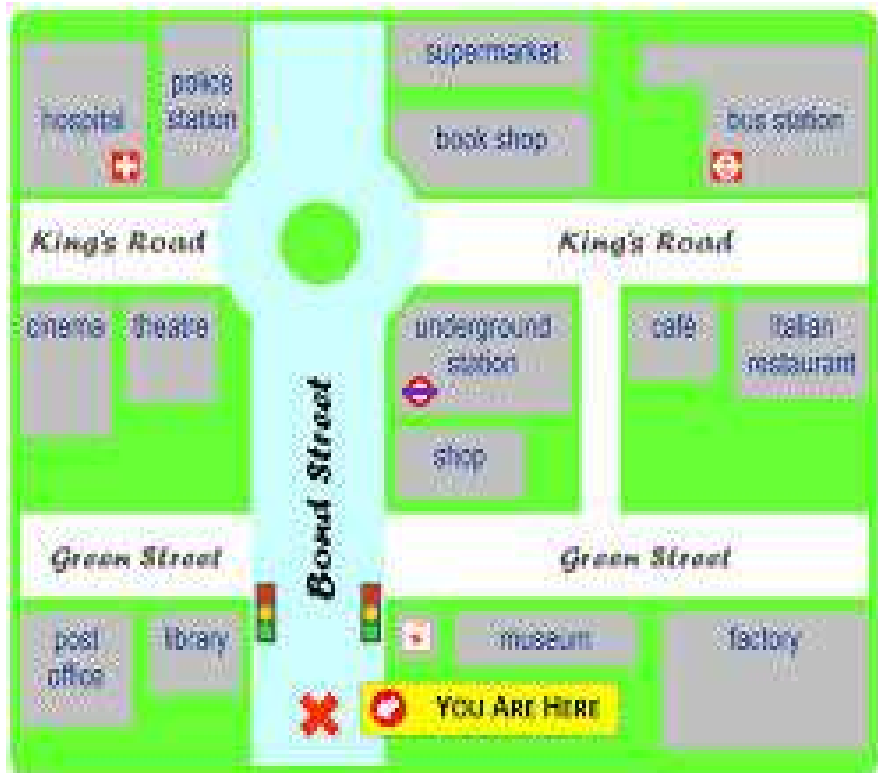




\section{Dialogue:}

A: Hello. How are you?

B: Good.

A: Can you help me, please?

B: Yes, sure.

A: Where's the police station?

B: It's just here, on Bond street.

A: How can I get there?

B: Walk straight ahead for three blocks. It's on the corner, to your left.

\section{Vocabulary}

\section{Common phrases:}

-Walk straight ahead/ Go straight ahead.

- On the corner, turn right.

-On the corner, turn left.

-It's in front of...

- It's behind.

-It's next to / It's beside.

-It's here. 
-It's over there.

- It's in front of you.

- It's next to you.

-It's behind you.

-Between.

-It's on the corner.

-It's on the left.

-It's on the right.

\section{GRAMMAR}

\section{You can use:}

\section{Between \& Among}

- Between is used when naming distinct, individual items. They can be two or more.

- Among is used when the items are part of a group, or are not specifically named. They are 3 or more.

This example will help illustrate the difference:

The conversation between Paul, Britney and John is going well.

The conversation among the students of my school is going well. 
Now practice with a partner

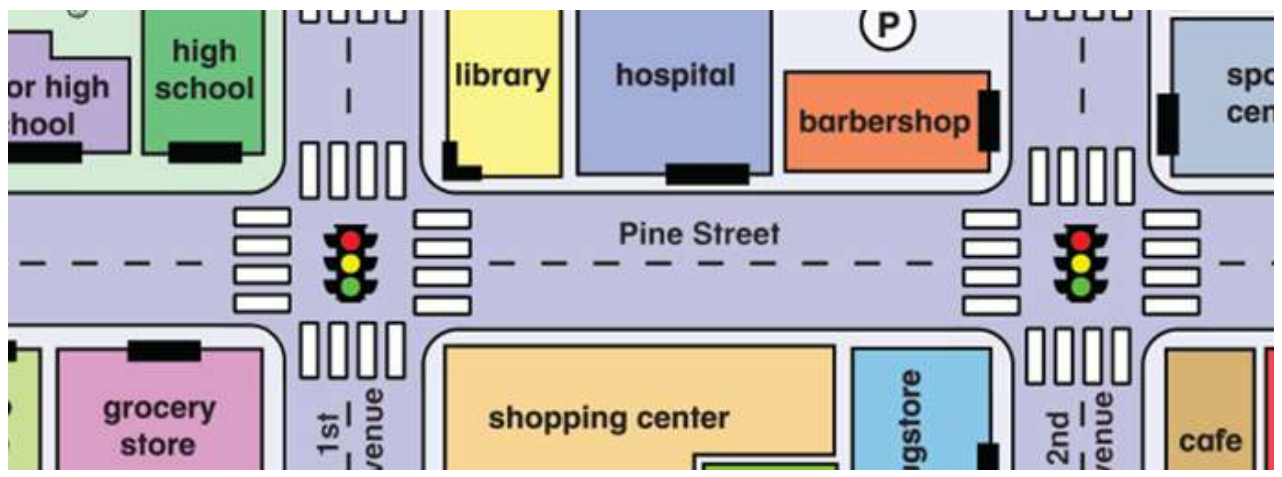

You are in your high school:

1. How do you get to the hospital?

2. Where the drugstore?

3. How can I get to sports center?

4. Where's the cafe? 


\section{Reading \\ Location of the Eiffel tower}

\section{THE EIFFEL TOWER}

When you think about France, what comes to mind? If you're like most people, you probably envision wine, art, mimes performing on street corners, and a really tall, pyramid-shaped structure.

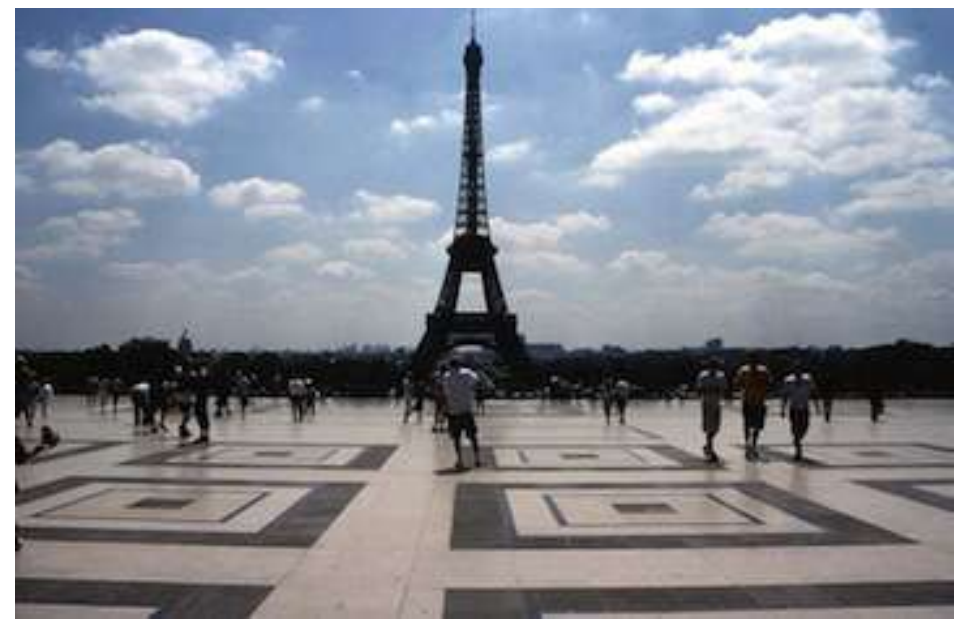

The Eiffel Tower is a national monument in Paris, France, that was designed by the company of civil engineer Gustave Eiffel. When it was completed in 1889 , it was the tallest man-made structure in the world at 1,063 feet tall. It has three visitor levels, two of which have restaurants. The top level is an observation tower 
situated 906 feet above the ground. The Eiffel Tower was an icon of French engineering and innovation in the 19th century, as well as a testament to the dominant role that France held in the world at that time.

\section{Say true or false:}

1. The Eiffel Tower is in Canada. T( )F( )

2. In 1889, it was the smallest man-made structure in the world. T ( ) F ( )

3. It has three visitor levels. T( )F ( )

4. It doesn't have restaurants. T( ) F ( )

\section{Answer the following questions:}

1. Who designed the Eiffel Tower?

2. Where is it?

3. When was it completed?

4. Was it an icon of French engineering and innovation in the 19th century? 



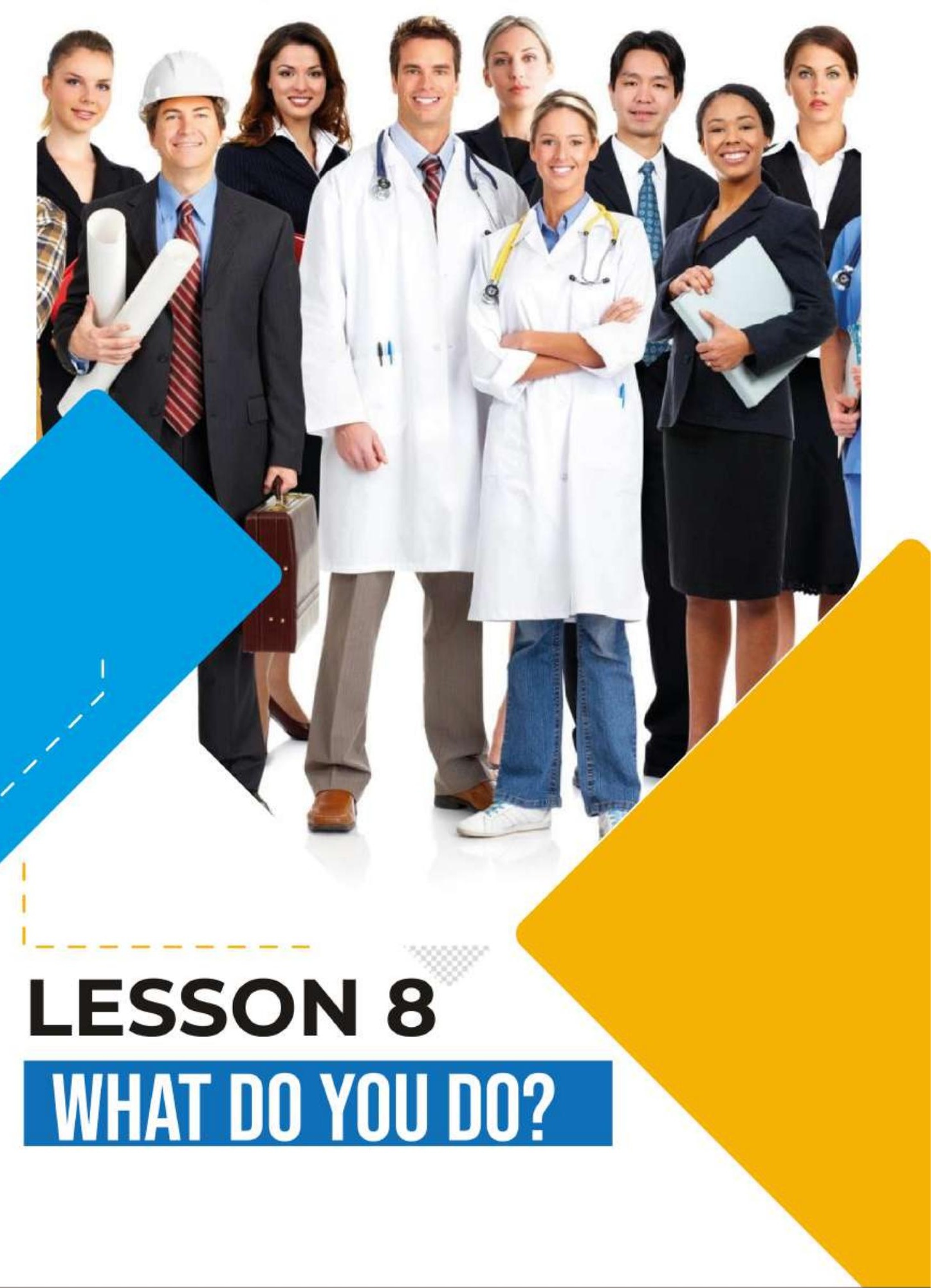





\section{LESSON 8}
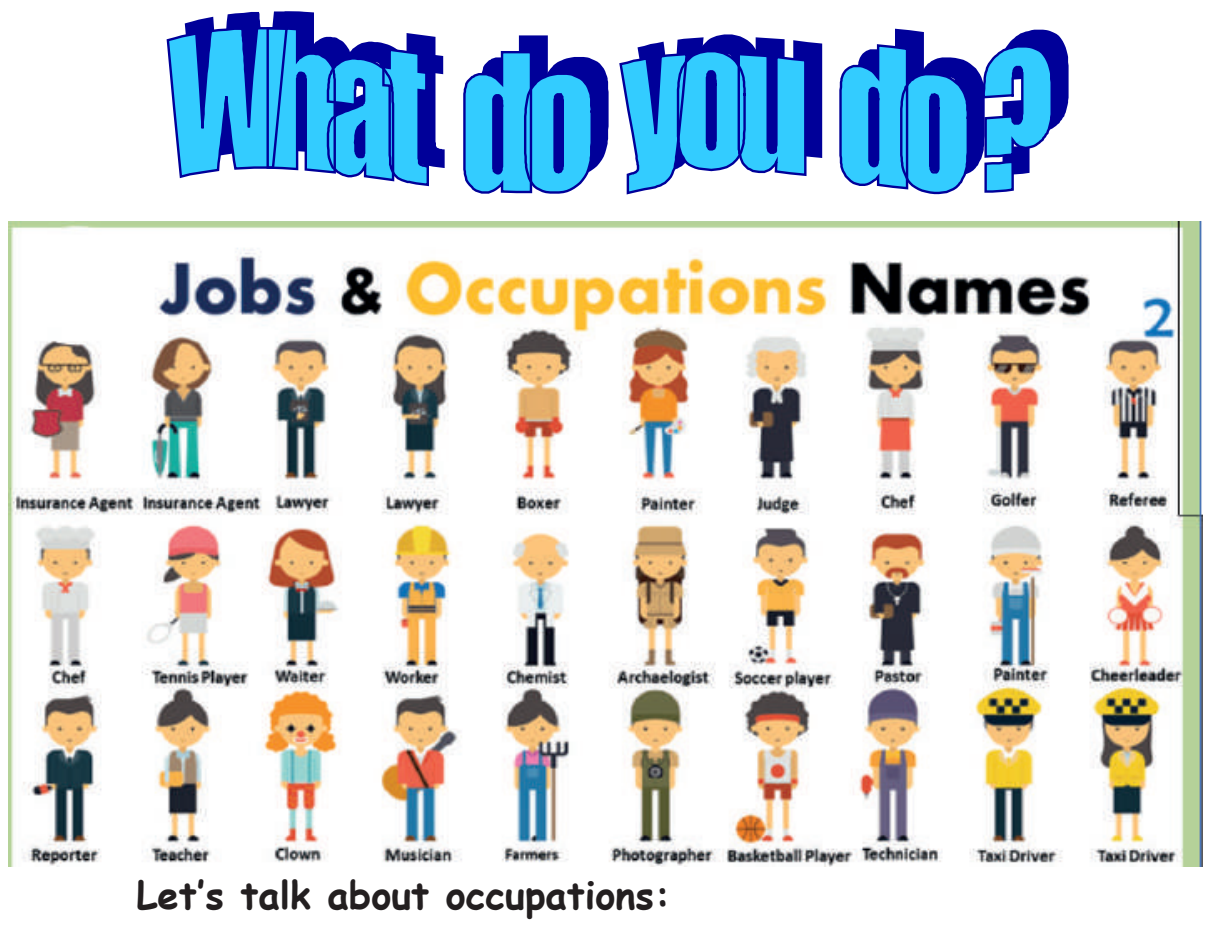

1. What do you do?

- I'm a teacher

2. Are you a photographer?

- No, I'm not. I 'm a reporter.

3. What do you do for a living?

- I'm a chef.

4. What's your occupation? 
-I'm a doctor.

5. What sort of work do you do?

- I'm a waiter/ waitress.

6. What line of work are you in?

- I work in restaurants.

You can see more expressions here: https://basicenglishspeaking.com/talking-jobs-occupations/

Place of work:

- Hospital

- Restaurant

- Shop

- Bookstore

- Factory

- Airport

- Call center

- Office

- School

\section{Job Status:}

- Employed

- Unemployed 
- Part-time job

- Full-time job

Dialogue:

A: Hello. How are you doing?

B: Great!

A: Why are you so happy?

B: Because I found a job.

A: Really! Congratulations. Where will you work?

B: In a school.

A: What kind of job?

B: English teacher.

A: Good for you!

B: Thanks a lot.

\section{VOCABULARY}

Jobs

Actor/ Actress- Architect- Air hostess-Bank clerk- book seller- Builder- cook- Dustman-Engineer- Farmer- Judge- Lawyer- Mechanic- Nanny- 
Nun- Policeman- Receptionist- Salesman- Secretary-

Shoemaker- Student- tailor- Vet- Waiter/ Waitress.

\section{GRAMMAR}

\section{You can use:}

As you can see. In spite of we ask: "what do you do?" You don't say I do a teacher, since it is incorrect. Instead of it, you use the verb to be to tell the answer because it allows you to tell directly the occupation that you perform, for example, I am an actor/actress, I am a teacher, and so on.

\section{$A \& A n$}

-You use the article " $a$ " when the next word starts with a consonant, for example, a doctor- a teacher.

- You use the article "an" when the next word starts with a vowel, for example, an engineer, an actor/actress.

\section{Exercices}

Write the correct form of the article: station occupation party octopus 


\section{Now practice with a partner}

1. Are you an engineer?

2. What do you do?

3. Where do you work?

4. Where is it?

\section{Recruitment}

The process of finding people for particular jobs is recruitment or, especially in Am. English, hiring. Someone who has been recruited is a recruit or, in Am. English, a hire. The company employs or hires them; they join the company. A company may recruit employees directly or use outside recruiters, recruitment agencies or employment agencies. Outside specialists called headhunters may be called on to headhunt people for very important jobs, persuading them to leave the organizations they already work for. This process is called headhunting.

\section{Applying for a job}

Fred is a van driver, but he was fed up with long trips. He looked in the situations vacant pages of his local newspaper, where a local supermarket was advertising 
for van drivers for a new delivery service. He applied for the job by completing an application form and sending it in. Harry is a building engineer. He saw a job in the appointment pages of one of the national papers. He made an application, sending in his CV (curriculum vitae - the "story" of his working life) and a covering letter explaining why he wanted the job and why he was the right person for it.

Note: $B r E: C V$; AmE: resume

BrE: covering letter; AmE: cover letter.

\section{Selection procedures}

Dagmar Schmidt is the head of recruitment at a German telecommunications company.

She talks about the selection process, the methods that the company uses to recruit people:

"We advertise in national newspapers. We look at the backgrounds of applicants: their experience of different jobs and their educational qualifications. We don't ask for handwritten letters of application as people usually apply by email; handwriting analysis belongs to the 19th century. We invite the most interesting candidates to a group discussion. Then we have individual interviews with each candidate. We also ask the candidates to do written psychological tests to assess their intelligence and personality. After this we shortlist three or four candidates. We check their references by writing to their referees: previous employers or teachers that candidates have named in their applications. If the references are OK, we ask the candidates to come back for more interviews. Finally, 
we offer the job to someone, and if they turn it down we have to think again. If they accept it, we hire them. We only appoint someone if we find the right person".

\section{Say true or false:}

1. A company doesn't care about recruiting employees directly or use outside recruiters. T ( ) $F($ )

2. Headhunting means to persuade people to leave the organizations they already work for. $T($ ) F ( ) 3. Dagmar Schmidt is the head of recruitment at a German telecommunications company. T( ) F ( )

4. A company only appoints someone if the employer finds the right person. T( ) F( )

\section{Answer the following questions:}

1. Where does a company advertise?

2. Who does it look for?

3. What does an employer do for hiring en employee?

4. What does a person have to fill to apply for a job? 





\section{LESSON 9}
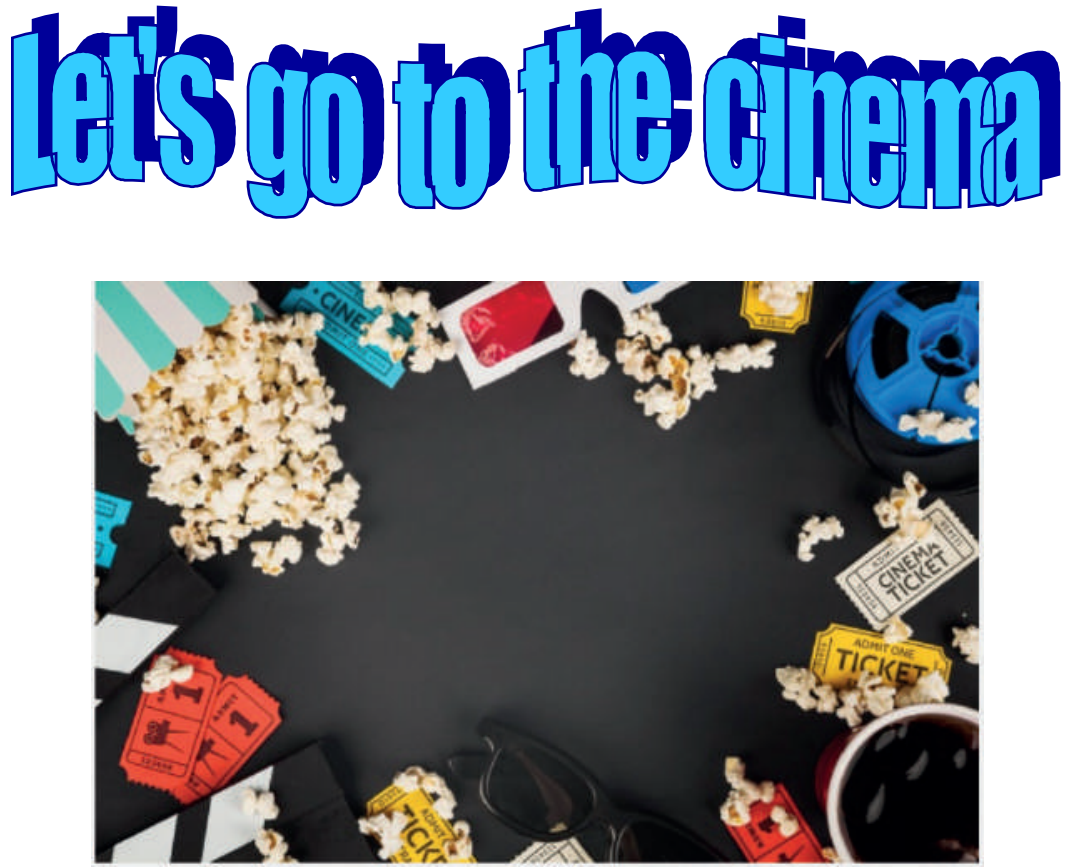

Let's talk about invitations and movies:

1. Would you like to go to the cinema?

- I'd love to.

- Sounds great!

-Yes, sure.

- I don't think I can.

- I'd love to, but... 
-I'm really sorry, but...

2. A: What's your favorite movie?

B: My favorite movie is Gone with the wind. What about you?

A: My favorite movie is Apple pie.

Kind of movies:

-Action films

-Horror films

-Adventure films

-Comic films

-Romantic films

-Drama films

\section{Vocabulary}

\section{About movies}

Script- Stuntman- Sound track- Special effectBlooper-box office- cast- critic- Flashback- SequelCameraman- Premiere.

\section{Adjectives}

Interesting- wonderful- handsome- beautiful- niceexcellent- thin-fat-tall-short-small- difficult- hard- 
easy.

Practice this dialogue:

A: What do you think about super hero movies?

B: I don't like them. I prefer romantic ones.

A: Really? What's your favorite romantic movie?

B: Revolutionary road.

A: Why?

B: Because of the script, the stars like Leonardo DiCaprio, for example. He 's my favorite actor. He's so handsome.

A: Ok. Well, I prefer action movies because they are very interesting and easier to understand. 


\section{GRAMMAR}

\section{You can use:}

\section{Comparative Adjectives:}

\section{Rules:}

\begin{tabular}{|c|c|c|c|}
\hline \multicolumn{4}{|c|}{$\begin{array}{l}\text { COMPARATIVE FORM + THAN } \\
\text { THE + SUPERLATIVE FORM }\end{array}$} \\
\hline & ADJECTIVE & I COMPARATIVE & SUPERLATIVE \\
\hline \multirow{4}{*}{$\begin{array}{l}\frac{0}{0} \\
\frac{0}{\bar{n}} \\
\frac{1}{n} \\
\frac{1}{c} \\
0\end{array}$} & Ending in... & $A D D$ & ADD \\
\hline & -e FINE & - $\mathrm{R}$ FINER & -ST FINEST \\
\hline & $\begin{array}{c}1 \text { vowel } \\
+ \\
1 \text { consonant } \\
\text { HoT }\end{array}$ & $\begin{array}{l}\text { double the consonant } \\
\text {-ER } \\
\text { HOTTER }\end{array}$ & $\begin{array}{l}\text { double the consonant } \\
\text {-EST } \\
\text { HOTTEST }\end{array}$ \\
\hline & $\begin{array}{c}\text { vowels } \\
+ \\
\text { consonants } \\
\text { FAST }\end{array}$ & $\begin{array}{l}-E R \\
\text { FASTER }\end{array}$ & $\begin{array}{l}\text {-EST } \\
\text { FASTEST }\end{array}$ \\
\hline \multicolumn{2}{|c|}{ Two Syllables ending in $-y$} & ${ }_{\text {HAPPIER }}^{\mathrm{Y} \rightarrow \mathrm{I}}$ & $\underbrace{\mathrm{r} \rightarrow \mathrm{EST}}_{\text {HAPPIEST }}$ \\
\hline \multicolumn{2}{|c|}{ Two Syllables or + not $-y$} & $\begin{array}{l}\text { MORE } \\
\text { before } \\
\text { MODERN }\end{array}$ & $\begin{array}{l}\text { MOST } \\
\text { before } \\
\text { MODERN }\end{array}$ \\
\hline \multicolumn{4}{|c|}{ IRREGULAR FORMS } \\
\hline & good & better & best \\
\hline & bad & worse & worst \\
\hline & little & less & least \\
\hline & much & more & most \\
\hline
\end{tabular}




\section{NOW PRACTICE WITH A PARTNER}

1. Are romantic movies easier to understand?

2. Are action movies more difficult to understand?

3. Are comic movies less boring?

4. Do you think horror movies are the worst?

\section{Reading}

\section{The Best Movies of 2019 (So Far)}

You know their names: Captain Marvel. John Wick: Chapter 3 - Parabellum. Avengers: Endgame. These were the movies that defined the first half of 2019 in a big way: Not only did they make a killing at the box office, they were also a hit with critics, each one awarded Certified Fresh certification for maintaining a high Tomatometer score, after scores of reviews.

Those movies join other prominent 2019 first-halfers like animated epics The LEGO Movie 2: The Second Part and How to Train Your Dragon: The Hidden World; comedies both big-scale (Shazam) and personal 
(Booksmart); this year's big musical biopic Rocketman; and documentary phenomenons like Amazing Grace, and Apollo 11. And all of those and more appear in our list of the best movies of 2019!

Taken from: https://editorial.rottentomatoes.com/ guide/best-movies-of-2019/

Say true or false:

1. Captain Marvel, Parabellum and Avengers defined the first half of 2019 in a big way T ( ) F ( )

2. Captain Marvel, Parabellum and Avengers were not key of critics. T ( ) F ( )

3. The films mantained a high score. $T($ ) $F($ )

4. Captain Marvel, Parabellum and Avengers are the only important films of 2019. T ( ) F ( )

Answer the following questions:

1. What are the most important films in 2019 ?

2. Were they a hit of critics?

3. What can you tell us about their score?

4. Which other films were important in 2019? 



\section{LESSON 10}
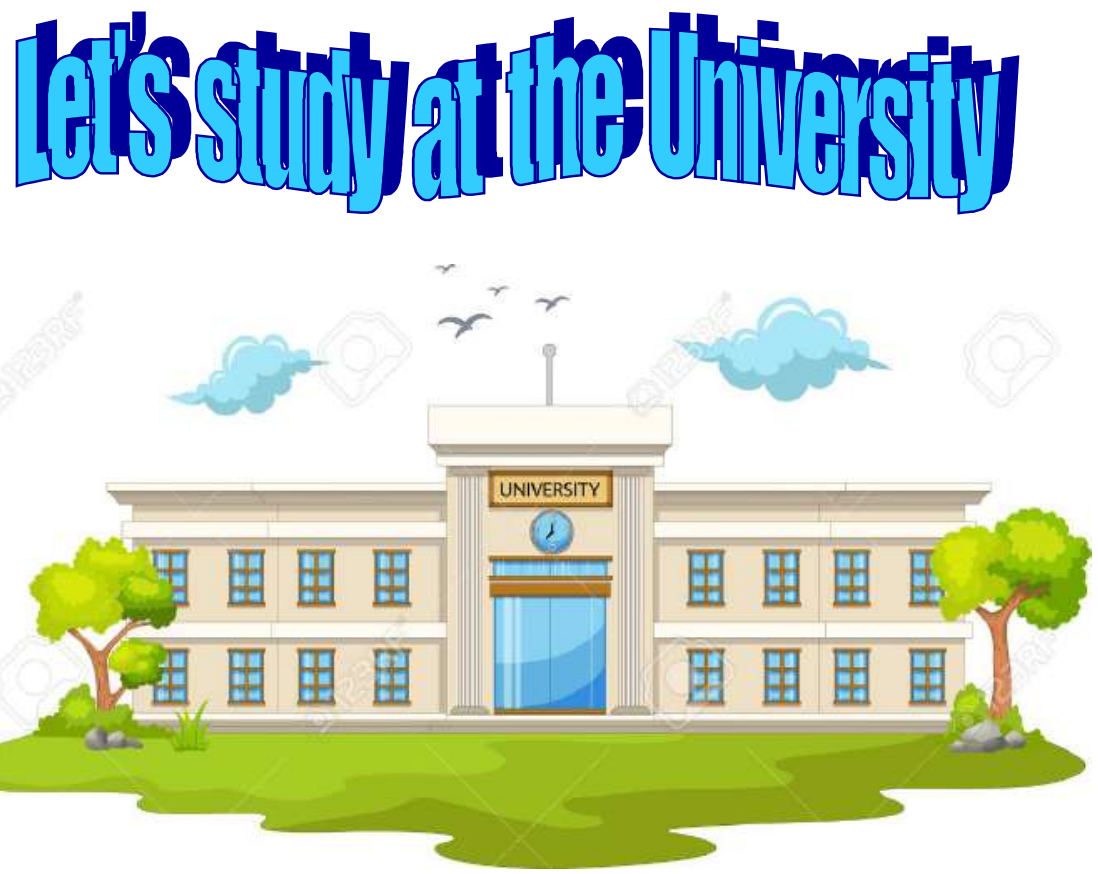

Let's talk about our studies:

Dialogue 1

A: When will we have the exposition?

B: On Monday.

A: What is the topic about?

B: It's about technology.

A: How can I start my presentation?

B: You have different options, you can say I want to 141 
make you a short presentation about... or I am delighted to be here today to tell you about...

A: Yes, good! And how can I talk about the purpose?

B: You can start saying: The purpose of this presentation is...

A: Good! I'll do it.

\section{Dialogue 2}

A: How can I register in the new semester?

B: Well, you have to visit the university page. Click on the option "registration". Download and fill in the form and send it to the university mail.

$A:$ Ah, it's easier than before.

B: Yes, it was more difficult because it was not on line.

A: Of course.

\section{Dialogue 3}

A: How has your life changed since beginning college?

B: Too much.

A: Why? 
B: Because I did not take so many notes in high school. A: How much note taking do you do in most of your classes?

B: A lot of.

A: What do you fear most about next semester's classes?

B: Writing. I don't like to write so much.

\section{Vocabulary}

Sophomore- junior- senior- roommate-counselor-spotback to back classes-college-freshman 


\section{GRAMMAR}

\section{You can use:}

Be going to \& Will

Will

We use it to ask for information about the future.

- He will be there in about an hour.

- My godmother will come to my party.

We also use it for decisions made at the time of speaking.

- We need some bread, I'll go and get it.

- What would like to drink? I will drink some coffee.

To make predictions about the future.

- I think he will come tomorrow.

To promise to do something.

- I promise I won't tell a word.

\section{Be going to...}

For plans or decisions made before speaking.

- Is daddy coming soon? - Yes, I'm going to look for him at the bus stop tomorrow.

- I'm going to listen to music in a minute, because my favorite programme is on.

\section{Can}

It is used in present or in future and to refer to abilities. 
YES YOU CAN !

\begin{tabular}{|c|c|c|c|}
\hline $\begin{array}{l}\text { Personal } \\
\text { Pronouns }\end{array}$ & Can & Questions & Answers \\
\hline$I$ & \multirow{9}{*}{ can } & Can you...? & I Can \\
\hline $\begin{array}{c}\text { You } \\
\text { (singular) }\end{array}$ & & Can I...? & You Can \\
\hline $\mathrm{He}$ & & Can he...? & He Can \\
\hline She & & Can she...? & She Can \\
\hline It & & Can it...? & It Can \\
\hline We & & Can you...? & We Can \\
\hline You & & \multirow{2}{*}{ Can we...? } & \multirow{2}{*}{ You Can } \\
\hline (Plural) & & & \\
\hline They & & $\begin{array}{c}\text { Can } \\
\text { they...?0 }\end{array}$ & They Can \\
\hline
\end{tabular}

Ejemplo,

*Can you go to class right now?

-Yes, I can. (Short)

-Yes, I can go class right now. (Long)

-No, I cannot. (Short) or I can't

-No, I cannot go to class right now. (Long) or

No, I can't go to class right now.

\section{Wh- Questions}

What / Where /When / Who / Which/Why/ How

1. What can I do for you? (just help me) 
-You can just help me, please.

Let's practice.

1. Can they practice today?

2. Can you travel next year?

3. Can you use the computer?

4. Can he speak louder? 
Adverbs of time: Now, right now, today, in the morning, in the afternoon, in the evening, next week, next year, next month, next time, tomorrow.

\section{NOW PRACTICE WITH A PARTNER}

1. What are you going to do?

2. Are you going to visit your family?

3. What will you do next year?

4. Will you travel to New York?

\section{Practice English on Your Own:}

\section{Self-study Ideas for English Language Learners}

Now that you are living in Manitoba, you have many reasons to improve your English. Communicating in English will help you to be successful at work and in your community.

English classes are available for free in Manitoba for permanent residents. You can choose from fulltime or part-time classes during the day or evening. However, not everyone can go to English classes. If you are working at a job every day and also taking care of a family, it can be very difficult to take time to go to classes. If you are able to take the time to go to 
English classes you may also want to learn faster and study at home. For these reasons it is useful to know some strategies for practicing English on your own.

There are many ways to learn English outside of the classroom. The ideas you will read about here are from adult EAL teachers and learners. You will find out about some of the many internet websites where you can learn for free as quickly or as slowly as you like. You will also find out more about the Canadian Language Benchmarks and think about what your level of English is right now, and what level you want it to be in the future. Information is also provided about some internationally recognized English language standardized tests.

Good luck as you practise your English communication skills!

\section{Say true or false:}

1. English communication helps people to be successful. $T($ ) F ( )

2. Manitoba does not give opportunity of study for permanent residents. $T($ ) $F($ )

3. There are not so many websites to learn English. $T($ ) $F()$

4. Standarized tests help people to think about what their level of English. T( ) F ( ) 


\section{YES YOU CAN！}

Answer the following questions:

1. Who has benefits to study in Manitoba?

2. How long can a student spend in their studies?

3. Can everybody go to class?

4. Which strategies can we take into account for studying a language?

Let's make a review and practice hard!

1. Make a long dialogue using greetings, introductory expressions, and farewells, word spelling, occupations, expressions to use in a restaurant, at the cinema, at the university and to talk about locations. 
YES YOU CAN !

150 



\section{English texts to practice Reading (Short Texts)}





\section{My day}

First, I wake up. Then, I get dressed. I walk to school. I do not ride a bike. I do not ride the bus. I like to go to school. It rains. I do not like rain. I eat lunch. I eat a sandwich and an apple. I play outside. I like to play. I read a book. I like to read books. I walk home. I do not like walking home. My mother cooks soup for dinner. The soup is hot. Then, I go to bed. I do not like to go bed.

Taken from: lingua.com 


\section{OUR HUMAN RIGHTS}

The United Nations is an international organization that was established in 1945 to help keep world peace. It was established shortly after the end of World War II.

In 1948 a special United Nations commission, headed by Mrs. Eleanor Roosevelt, the wife of US President Franklin D. Roosevelt, wrote a special document which stated the rights that all people should have. This document is called the "Universal Declaration of Human Rights."

Taken from: lingua.com 


\section{Food and Shelter for All}

It is Benny's tenth birthday. To celebrate, his parents take him out to eat at a fancy restaurant.

The food is delicious, but there is a lot of it, so Benny has leftovers to take home. He is excited about this. The server gives him a paper bag full of his extra food.

Benny and his parents walk down a busy street toward their parked car. Benny sees an older man on the sidewalk. He sits with his back against a building. He looks very tired and hungry. He holds a sign that says, "Will work for food."

Taken from: https://www.really-learn-english.com/ english-reading-practice-article-27.html 


\section{The city where I live}

My name is Clark, and I will tell you about my city.

I live in an apartment. In my city, there is a post office where people mail letters. On Monday, I go to work. I work at the post office. Everyone shops for food at the grocery store. They also eat at the restaurant. The restaurant serves pizza and ice cream.

My friends and I go to the park. We like to play soccer at the park. On Fridays, we go to the cinema to see a movie. Children don't go to school on the weekend. Each day, people go to the hospital when they are sick. The doctors and nurses take care of them. The police keep everyone safe. I am happy to live in my city.

Taken from: lingua.com 


\section{English texts to practice Reading (Long Texts)}





\section{Valentine's Day}

Valentine's Day (or Saint Valentine's Day) is a holiday that, in the United States, takes place on February 14, and technically signifies the accomplishments of St. Valentine, a third-century Romansaint. With that said, most Americans, instead of honoring St. Valentine through religious ceremony, enjoy the holiday by engaging in "romantic" behavior with their significant other or someone who they wish to be their significant other; gifts, special dinners, and other acknowledgements of affection comprise most individuals' Valentine's Day celebrations. Chocolates and flowers are commonly given as gifts during Valentine's Day, as are accompanying greeting cards (greeting card companies release new Valentine's Day designs annually). Red and pink are generally understood to be "the colors" of Valentine's Day, and many individuals, instead of celebrating romantically, spend the holiday with their friends and/or family members. Variations of Valentine's Day are celebrated across the globe throughout the year. In America, the holiday, although acknowledged by the vast majority of the population, isn't federally recognized; no time off work is granted for Valentine's Day.

Taken form: lingua.com 


\section{Jobs and Professions}

As has been the case for many years, jobs, or forms of employment wherein employees perform a service or duty in exchange for financial compensation, play a prominent role in society. Furthermore, all jobs-even those of seemingly little significanceare important, as they simply wouldn't exist if their specific responsibilities weren't of value to employers (companies or persons that pay others for their work), customers (individuals who pay money for a product or service), and the economy generally. Teachers, or educational professionals tasked with helping students understand certain subjects and topics, are especially crucial today. In short, teachers help their students to become qualified for their future careers. Doctors, or medical professionals who specialize in providing health-related assistance to patients, are some of the most respected individuals in America and the world. It's the responsibility of doctors to help those who feel less-than-stellar to determine the underlying health issue(s) and recommend an effective treatment (or remedy to a disease, disorder, or condition). There are quite a few types of specialty doctors in America (besides MD, which simply means "medical doctor"), all of whom can be referred to simply as "Doctor (Name)." Dentists (mouth/teeth doctors), dermatologists (skin doctors), and psychiatrists (mental-health doctors) are just a few examples of the many different types of doctors. Additionally, nurses are medical professionals 
who help to administer doctor-ordered treatments to patients. Police officers are law enforcement professionals whose job it is to protect citizens, solve crimes, and assure that rules and regulations are followed. Similarly, firefighters serve the public by responding to fires (and other emergency situations) and using high-tech equipment to extinguish these fires, whilebringing any individuals who're in danger to safety. Farmers maintain fields of crops (or vegetable/fruit plants) and/or collections of animals with the intention of selling these products as food. Chefs/cooks prepare meals in professional settings, including restaurants, cafeterias, and other venues wherein food and drink are sold, for customers. Chefs are generally experienced in cooking and managing kitchens. Waiters bring menus, beverages, meals, and ultimately, the check (or a bill of the foods and drinks purchased in a transaction) to tables in restaurants and other establishments that serve food. Artists produce art, or works of creative significance, including music, paintings, drawings, poetry, writing, and more. 


\section{Going to a restaurant}

Dialogue

Sandra and Paul are at a steak restaurant. A waiter greets them.

"Doyouknow whatyouwould like to drink?" thewaiterasks. "Water and orange juice," Sandra says. "Thank you. Here are your menus," the waiter says.

The waiter brings water for Paul and orange juice for Sandra.

"What would you like to order?" the waiter asks. "I would like a 12-ounce steak and mashed potatoes," Paul says.

"The same thing, but with green beans," Sandra says. "And two orders of garlic bread," Paul says. "Great. You should have it in soon," the waiter says.

The waiter returns after an hour.

"Sorry for your wait. Here are two orders of 12-ounce steaks with mashed potatoes and garlic bread," the waiter says.

"I asked for green beans with mine," Sandra says. 
"I'm sorry, I'll get those for you," the waiter says.

The waiter quickly returns with Sandra's green beans.

Taken from: lingua.com

\section{Going to the Supermarket}

Martha is at the grocery store, getting ready for a house party. She has a list of what she needs with her as she goes along. The first section she comes has produce. Martha sees apples, bananas, cherries, grapes, and strawberries. She checks her list:- 6 apples- 1 bag of cherries- 1 bag of grapes- 2 cartons of strawberries. Martha get her items and looks the bananas. They are on sale for much cheaper than they are normally. She picks 3 bananas. Next are vegetables. She sees potatoes, carrots, tomatoes, onions, mushrooms, and salad in bags. She checks her list:- 5 pounds of potatoes- 6 carrots- 4 tomatoes2 onions- 4 mushrooms. As she is putting her items into her cart, Martha checks the many bags of salad and chooses 2 of them. She pushes her cart ahead. The next section is meat and dairy. She sees meat, fish, cheese, eggs, and milk. She checks her list:- 2 fish (salmon)- 1 block of cheese (cheddar) - 1 dozen eggs- 2 gallons of milk. She looks at the meat that is on sale and chooses a 5-pound roll of hamburger. She gets the rest of the items in that section. She still 
needs rice, bread, salt, sugar, and flour. She gets:- 2 bags of rice- 4 loaves of bread-a 2-pound bag of sugar - a 2-pound bag of flour Martha then realizes that she has forgotten something. She runs back and gets 1 container of salt and then rushes to the checkout. She puts her groceries into her car and leaves.

Taken from: lingua.com 


\section{Christmas}

A Christian holiday signifying the birth of Jesus, Christmas is widely celebrated and enjoyed across the United States and the world. The holiday always falls on 25 December (regardless of the day of the week), and is typically accompanied by decorations, presents, and special meals. Specifically, the legend behind Christmas (and the one that most children are told) is that Santa Claus, a bearded, hefty, jolly, and red-jacket-wearing old man who lives in the North Pole, spends the year crafting presents with his elves, or small, festive, excited Santa-assistants. All the children who behave throughout the year are admitted to the Good List, and will presumably receive their desired gifts on Christmas, while those who don't behave are placed on the Naughty List, and will presumably(although the matter is determined by parents) receive a lump of coal. Santa Claus is said to fly around the Christmas sky in a sled powered by his magical reindeer, or coldresistant, mythically powered, individually named animals, delivering presents to each child's house in the process. Santa is also expected to slide through chimneys to deliver these presents (homes not equipped with chimneys might "leave the front door cracked open"), and children sometimes arrange cookies or other treats on a plate for him to enjoy. Gifts are placed underneath a Christmas tree, or a pine tree that's decorated with ornaments and/or lights and 
is symbolic of the holiday. Additionally, smaller gifts may be placed inside a stocking, or a sock-shaped, holiday-specific piece of fabric that's generally hung on the mantle of a fireplace (homes without fireplaces might use the wall). A Christmas tree's ornaments, or hanging, typically spherical decorations, in addition to the mentioned lights, may be accompanied by a star, or a representation of the Star of Jerusalem that the Three Apostles followed while bringing Baby Jesus gifts and honoring him, in the Bible.

Taken from: lingua.com 


\section{The pet store}

George is at the pet store, looking at what kind of pet he might want to get for his birthday. George asked if he could have a horse, but his parents said no because horses are too big. First, he sees dogs and cats. Baby dogs are called puppies. Baby cats are called kittens. George likes them because they are easy to take care of and can play a lot, but they will get bigger. George wants a small pet.

Then George sees animals that have to live in a cage. He sees rabbits, guinea pigs, and mice. Mice are what you call more than one mouse. He likes these animals because they are small. Birds live in cages too. George sees a parrot and a canary. He likes them all, but he doesn't want to clean the cage.

George sees the animals in tanks. The tanks full of water have fish and turtles in them. He thinks about a goldfish but decides he likes the turtles more. There are also tanks with rocks and sand that have snakes, spiders, and scorpions, but George is afraid of them. George likes the turtles best, but they won't fit in the little fishbowls. Turtles need bigger tanks, so they can swim sometimes and hide sometimes. George decides he wants to get a turtle for his birthday. He buys a book on how to take care of a turtle and a list of what types of turtles the store has.

Taken from: lingua.com 


\section{The four seasons}

The four seasons are spring, summer, fall, and winter, and although various areas of the United States experience drastically different weather during these times, all portions of the country recognize the seasons; winter in California may bring heat, and winter in New York may bring blizzards, but both periods are nevertheless winter.

Following winter, spring begins on 20 March and ends on either 20 June or 21 June, in the United States (this date may vary slightly from year to year and hemisphere to hemisphere). For most, spring is a time of "thawing," when the cold and snow of the winter are replaced by sunshine, reasonable temperatures, green grass, and more. It is also the season wherein previously dormant bees and butterflies reemerge, and when birds become more active.

Summer follows spring and spans from about 21 June to 22 September, in America. Summer is the warmest, the longest, and (arguably) the liveliest of the four seasons; students from kindergarten to college are given two or so summer months off from class, and to be sure, there are more young individuals out and about during this season than any other. It's not uncommon to see shorts, t-shirts, and sunglasses worn by those who're soaking up the summer's hot sun, and to stay cool, many individuals crank the air conditioning, take 
a dip in a swimming pool, and/or explore the evercomforting ocean waves.

Autumn (or fall), more than being a simple precursor to winter, is one of the most beautiful and exciting seasons. Spanning from 22 September to 21 December (technically, that is; snow will begin to fall long before this latter date, in most parts of the country, leading many to classify the period as winter) in the US, autumn is characterized by falling leaves, Halloween (on 31 October), and Thanksgiving. During fall, traditional farmers harvest their produce, and the aforementioned falling leaves change to gorgeous orange, red, and yellow colors; these colors are generally associated with autumn itself, in turn.

In the US, winter spans from 21 December to 20 March, and is, as one would expect, the coldest of the four seasons. In the eastern, northern, and central portions of the country, winter snowfall can be considerable; in the western and southern portions of the country, winter snowfall is highly unlikely, but temperatures nevertheless drop from their usual. Winter is most widely known for its snow and the Christmas holiday, but it also boasts New Year's Eve (on December 31, in recognition of the start of a new year) and other special days. Ice skating, sledding, ice hockey, and snowball fights are commonly enjoyed winter activities. Taken from: lingua.com 


\section{Preparing food}

Jack was hungry. He walked to the kitchen. He got out some eggs. He took out some oil. He placed a skillet on the stove. Next, he turned on the heat. He poured the oil into the skillet. He cracked the eggs into a bowl. He stirred the eggs. Then, he poured them into the hot skillet. He waited while the eggs cooked. They cooked for two minutes. He heard them cooking. They popped in the oil.

Next, Jack put the eggs on a plate. He placed the plate on the dining room table. Jack loved looking at his eggs. They looked pretty on the white plate. He sat down in the large wooden chair. He thought about the day ahead. He ate the eggs with a spoon. They were good.

He washed the plate with dishwashing soap. Then, he washed the pan. He got a sponge damp. Finally, he wiped down the table. Next, Jack watched TV.

Taken from: lingua.com 


\section{Numbers}

Most individuals don't think about numbers, or numerical representations of quantity, but they play a major part in everyday life. To be sure, numbers determine the time individuals will wake up in the morning, how much money employees earn per hour, what day of the year it is, and much, much more.

Additionally, numbers impact everyday living on a much smaller scale. In the grocery store, for instance, numbers determine products' prices, the amount of a product available for purchase, how much money will need to be paid for products, and a whole lot else.

To understand larger (and more intimidating numbers), interested persons first need to understand basic numbers, or numbers from one to ten, as they comprise each and every advanced number, or a multi-digit number that indicates a larger amount/quantity.

The basic numbers are as follows:

\section{One (1)}

Example: "He purchased one watermelon from the grocery store."

\section{Two (2)}

Example: "She bought two types of bread from the 173 
store."

Three (3)

Example: "He decided to get three bags of onions when he went shopping."

Four (4)

Example: "In preparation for the party, Janice bought four cartons of ice cream at the store."

Five (5)

Example: "Joe picked up five boxes of cereal from the breakfast aisle."

$\operatorname{Six}(6)$

Example: "A pound of beef costs a lot of money at my favorite grocery store."

\section{Seven (7)}

Example: "Seven of the 10 aisles at my local grocery store contain pasta."

\section{Eight (8)}

Example: "I bought eight cookies for the price of four at the store." 


\section{Nine (9)}

Example: "There were only nine loafs of bread left at the grocery store."

\section{Ten (10)}

Example: "Ten pineapples sure is a lot, don't you think?"

After ten, eleven (11), twelve (12), thirteen (13), fourteen (14), fifteen (15), sixteen (16), seventeen (17), eighteen (18), nineteen (19), and twenty (20) follow. These numbers are seen less in grocery stores, as most prices are 10 dollars or less; it is however worth knowing these numbers, generally and, in terms of grocery shopping, for when the bill must be paid.

After twenty, numbers such as twenty-five (25), fifty (50), seventy-five (75), and one hundred (100) follow. So long as one knows the core number, or the number situated in the tens or hundreds position that determines the general amount, understanding these more complicated numbers won't be difficult. For example thirty-three (33) is simply "thirty" plus three; sixty-seven is "sixty" plus seven; and sixty-nine is simply "sixty" plus nine.

Taken from: lingua.com 


\section{Thanksgiving}

Thanksgiving is a holiday celebrated predominantly in North America, and it possesses a different meaning in each of the countries where it's acknowledged.

In the United States, Thanksgiving is a federal holiday (meaning all government employees and most private employees are given a day off of work), and always takes places on the Fourth Thursday in November, regardless of the date.

The holiday signifies the immense progress made by pilgrims, or some of the first travelers to North America, at Plymouth Plantation circa 1621. It was at this time that the hungry and weary Pilgrims were taught (by Native Americans) how to grow and produce food on North America's unique terrain. Once they'd grown (and caught) an abundance of food, the Pilgrims were expectedly thankful, and they celebrated alongside the Native Americans who provided them with such valuable assistance. President Abraham Lincoln initiated the contemporary practice of Thanksgiving by calling for a "day of Thanksgiving" during one of his Civil War addresses.

In Americatoday, Thanksgiving remains firmly engrained in its historical roots, and is widely considered to be a day for giving thanks for good food, good times, and family. Thanksgiving dinner generally consists of 
turkey, mashed potatoes, stuffing, vegetables, gravy, and ample desserts. To be sure, indulging in abundance is a cornerstone of the holiday, as doing so could only be possible if one possesses abundance.

Taken from: lingua.com 


\section{At school}

Lucas goes to school every day of the week. He has many subjects to go to each school day: English, art, science, mathematics, gym, and history. His mother packs a big backpack full of books and lunch for Lucas.

His first class is English, and he likes that teacher very much. His English teacher says that he is a good pupil, which Lucas knows means that she thinks he is a good student.

His next class is art. He draws on paper with crayons and pencils and sometimes uses a ruler. Lucas likes art. It is his favorite class.

His third class is science. This class is very hard for Lucas to figure out, but he gets to work with his classmates a lot, which he likes to do. His friend, Kyle, works with Lucas in science class, and they have fun.

Then Lucas gets his break for lunch. He sits with Kyle while he eats. The principal, or the headmaster as some call him, likes to walk around and talk to students 
during lunch to check that they are all behaving.

The next class is mathematics, which most of the students just call math. Kyle has trouble getting a good grade in mathematics, but the teacher is very nice and helpful.

His fourth class is gym. It is just exercising.

History is his last class of the day Lucas has a hard time staying awake. Many lessons are boring, and he is very tired after doing gym.

Taken from: lingua.com 


\section{Letter to a Friend}

Hi, Fred!

It's been a while since we have been in touch. How has your semester been?

I wanted to send you an email update to you let you know how things have been going during my semester abroad here in Málaga, Spain. I've already been here for six weeks, and I feel like I am finally adapting to the culture. I'm also speaking the language more fluently.

I arrived during the first week of September. The weather has been very nice. Even though it's October, it's still rather sunny and warm. In fact, I went to the beach and swam in the Mediterranean Sea earlier today.

I am living with a very welcoming host family. I have my own private bedroom, but we eat breakfast, lunch, and dinner together. On Sundays, we eat a big homecooked paella for lunch. In Spain, lunch is usually the biggest meal of the day. It's also very common for the people to take a midday nap right after a big meal. I am actually just waking up from my nap right now!

On weekdays, I take classes at the local university. There, I met several native Spanish speakers. They 
have been very kind and patient with me. At first, I struggled to comprehend their Spanish, but now I understand most of our conversations. They have commented that my Spanish has improved a lot since we first met. Now, I am more confident to use the language in other places like stores and restaurants.

I am so glad that I decided to spend the semester here in Spain. We have an extended weekend coming up, so a group of my friends and I are going to travel to France for four days. It's so easy and inexpensive to travel internationally in Europe. I love it!

I look forward to hearing from you soon. Like I said, don't hesitate to stay in touch more often. Perhaps you could even come to visit! What do you think?

Best wishes, Patrick

Taken from: lingua.com 





\section{PROFICIENCY TEST $100 \%$}

\section{PART I}

1. Pronounce the following words (Send it via the virtual room): (15\%)

a. Either

b. Itch

c. Egg

d. Edge

e. Apple

f. Ate

g. Oil

h. Oat

i. All

j. Fall

k. Awe

I. Cook

m. Hood

n. Woman

o. Food

p. Do 
q. Us

r. Ago

s. Urgent

t. Eye

\section{PART II}

2. Spelling. Spell the following words (Send it via the virtual room): (15\%)

a. Computer:

b. Schwarzenegger:

c. Proficiency:

d. Yellow:

e. Television:

f. Truth:

g. Pillow:

h. Bed:

i. Acknowledgment:

j. Bride: 


\section{PART III}

3. Answer the questions: (10\%)

a. What's your first name?

b. How do you spell it?

c. What's your surname?

d. How do you spell it?

\section{PART IV}

4. Use the correct possessive adjective: (10\%)

a. She is very intelligent. What's name?

b. That man is tall. What's size?

c. A: Wow! That's building is big.

B: Which one? Tell me color.

A: The red one.

d. A: They are my classmates.

B: What are names? 


\section{PART V}

5. Answer these questions: (10\%)

a. What do you do?

b. Does your teacher miss classes?

c. Do your classmates go to class every day?

d. What time are the stores open in your country?

e. Are they closed at 9 pm or before?

f. If you go to a store, you will pay in cash or by card?

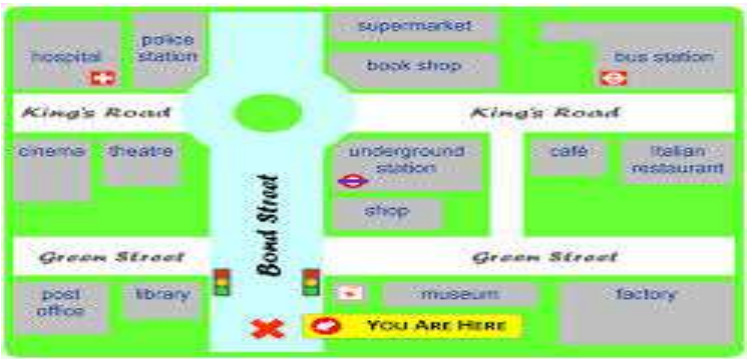




\section{PART VI}

a). Write a dialogue in which you ask for food in a restaurant and talk about the time because you must go to the airport to attend your sister's graduation. (20\%)

\section{PART VII}

a). You will have a conversation with your teacher about personal information. Keep in touch to connect via web chat. (20\%)

SUCCESS! 



\section{REFERENCES}

-Ali, O. (s/f). El curso más completo de inglés.www.formacionveracruz.tk.

-Augusto, G. (s/f) El Juego como Estrategia para el Desarro $\neg$ llo de la Expresión Oral del Inglés en los Estudiantes de la Modalidad de Aprendiza $\neg$ je Dialógico Interactivo (ADI). Editorial Iztaccihuatil, S.A. Uruguay N0 17. México, D.F.

-Burt, M., Peyton, J. y Adams, R. (2003). Reading and Adult English Language Learners. A review of the research. Center for Applied Linguistics. Washington, DC.

-Cambridge Learner's Dictionary [with CD-ROM] (2001). Cambridge: Cambridge University Press.

-Diccionario Cambridge Klett Pocket, Español-Inglés/English-Spanish (2002). Cambridge: Cambridge University Press.

-García, C. (2013) El Juego como Estrategia para el Desarro $\neg$ llo de la Expresión Oral del Inglés en los Estudiantes de la Modalidad de Aprendiza $\neg$ je Dialógico Interactivo (ADI). DIGICIENCIA UDEFA Vol. 2, Octubre 2013. Dep. legal ppi201202FA4181. Universidad de Falcón.

-Gran Diccionario Oxford. Español-Inglés. Inglés-Español (2003). Oxford: Oxford University Press.

-Imhoof, M. From Paragraph to Essay: Developing Composition Writing. Longman. 
-McArthy, M. y O’Dell, F (1999). English Vocabulary in Use. (Elementary) CUP.

- Malíková, D. y Malíková, J. (s/f). A practical english handbook for bachelor students. Brno University of Technology Faculty of Electrical Engineering and Communication Department of Languages.

-Ministerio de Educación Nacional (2010). I like English. Modelo Educativo. Aceleración del aprendizaje. I Proyecto.

- Nikolaenko, E. (2008). Business english. Tomsk Polytechnic University Publishing House.

-Practise English on Your Own Self-study Ideas for English Language Learners. Manitoba.

-Vince, M. (2009) First Certificate. Language Practice with Key. English Grammar and Vocabulary (4th Edition). Macmillan.

-Zur, O. (2011). English Short Stories Emma and Jerry. www.really-learn-english.com. 